NBER WORKING PAPER SERIES

\title{
SOCIAL SECURITY AND RETIREMENT IN SPAIN
}

Michele Boldrin

Sergi Jimenez-Martin

Franco Peracchi

Working Paper 6136

\section{NATIONAL BUREAU OF ECONOMIC RESEARCH 1050 Massachusetts Avenue Cambridge, MA 02138 \\ August 1997}

This paper is part of the NBER Project on International Social Security Comparisons. We thank Jon Gruber and David Wise for their comments, Almudena Duran and Vincenzo Galasso for helpful discussions, and Luis Martin for his research assistance. Financial support from DGICYT (Project \#PB94-0378), CICYT (Project \#SEC96-0738), and the Fundación Marc Rich is gratefully acknowledged. This paper is part of NBER's research programs in Aging and Public Economics. Any opinions expressed are those of the authors and not those of the National Bureau of Economic Research.

(C) 1997 by Michele Boldrin, Sergi Jimenez-Martin and Franco Peracchi. All rights reserved. Short sections of text, not to exceed two paragraphs, may be quoted without explicit permission provided that full credit, including $(\mathcal{O}$ notice, is given to the source. 
Social Security and Retirement in Spain

Michele Boldrin, Sergi Jimenez-Martin

and Franco Peracchi

NBER Working Paper No. 6136

August 1997

Aging and Public Economics

\begin{abstract}
We describe the historical evolution of the Spanish Social Security system and its current organization. Our attention concentrates on the main public pension scheme for private employees in the manufacturing and service sector (RGSS) which covers by far the largest majority of Spanish workers. After describing the way in which pension and retirement decisions are regulated by this system, we try to compute the incentives to early retirement it provides to different kinds of individuals. We show that the Spanish SS legislation generates strong incentives to retire early and that Spanish workers tend to do so.

In particular, our findings support the idea that pensions-induced incentives matter for the labor supply behavior of Spanish workers. While the Spanish system does not pay a particularly generous average pension relative to GDP per-capita, its "generosity" concentrates on providing large minimum pensions to individuals with below average working histories and/or low wages. At the same time, the pension system provides workers earning average or above average salaries and with complete working histories with relatively weak financial gains from not retiring after the age of 60 .
\end{abstract}

The combination of these features of the Spanish legislation seems to account well for the observed increase in the percentage of early retirees among Spanish pensioners during the nineties.

Michele Boldrin

Departamento de Economía

Universidad Carlos III de Madrid

28903 Getafe - Madrid

SPAIN

Franco Peracchi

DMQTE

Università d'Annunzio

I-65127 Pescara

ITALY
Sergi Jimenez-Martin

Departamento de Economía

Universidad Carlos III de Madrid

28903 Getafe - Madrid

SPAIN 


\section{Introduction}

Public pensions represent the most important welfare program in Spain, absorbing almost 70 percent of the total expenditure for social protection programs, and representing about 11.5 percent of GDP in 1994. Average annual growth rate of public pension expenditures over the period $1980-95$ has been 13.1 percent, about 1.5 times higher than the GDP growth rate.

All available studies indicate a progressive worsening of the financial situation of the Social Security system (sistema de la Seguridad Social), the most important public pension program in Spain. While we concentrate here on the retirement incentives provided by the current system without addressing its long-run viability, a brief overview of its aggregate evolution is useful to place the subsequent analysis in a proper perspective.

The fraction of annual Social Security (SS) expenditures which is covered through direct contributions, from either workers or employers, has decreased steadily from 89.4 percent in 1980 to 66 percent in 1995 , the difference being made up by increasingly large transfers from the government. Even the most optimistic projections forecast a continuous increase in the current account deficit of the Spanish SS system. Normalizing to zero the deficit of the pension system in 1995 , the deficit in 2010 is expected to range between .8 and 3.5 percent of GDP [Herce (1997)]. The worsening of the deficit reflects the expectation that the growth of SS revenues will not be able to keep up with the strong increase in SS expenditures, which should grow in real terms between 2.5 and 3.2 percent annually over the next two decades.

As we explain in more detail below (Section 3), the current SS system provides five types of contributory pensions: old-age, disability, widowers, orphans, and other relatives. Over the three subperiods $1980-85,1985-90$ and $1990-95$, 
total expenditure on each type of contribution-based pension has grown in real terms at annual rates given in Table 1 . The most important source of pension expenditure growth has been demographic changes, followed by the widening of coverage, and the increase in real average pensions. We now provide some aggregate indices of the more recent evolution of these three factors.

Life expectancy at birth has increased by seven years over the last three decades, from 69.9 years in 1960 to 76.9 in 1991 . This, together with the concurrent sharp decline in natality rates and the impact of the aging baby-boomers, is reflected in Figure 1, which presents the basic trends in the structure of the population of working age $(16+)$ over the last twenty years. We distinguish between men and women and 3 broad age groups: $16-24,25-54$ and $55+$. The fraction of 16-24 reached a peak between 1982 and 1987 and has been falling since. The fraction of $25-54$ has been declining till 1988 and is now rising as the baby boomers get older. On the other hand, the fraction aged $55+$ has been increasing steadily, although at a decreasing rate.

Over the three intervals $1980-85,1985-90$ and $1990-95$, the annual growth rate of the total number of public pensions has been equal to $4.2,2.8$ and 2.8 percent respectively (Table 1 ). As of 1994 , the total number of contributory pensions outstanding was equal to 6.9 millions according to the official SS records, of which 3.2 millions for old-age, 1.7 millions for disability, 1.8 millions for survivors, 168 thousands for orphans and 42 thousands for other relatives.

The third factor, namely the increase in the real value of average pensions, is also captured in Table 1, which reports the annual growth rate of real average pensions for each group and time interval. Notice that Spanish pensions are not particularly generous, at least with respect to the European average. For example, the average pension in 1994 was equivalent to only 47 percent of percapita GDP against a European average of 62 percent. In the same year, the 
average pension was equal to 63 percent of the average wage and 70 percent of the pensions were below the minimum wage.

This fact suggests, as a tentative hypothesis, that the financial imbalance of the Spanish system may not come from its particular generosity but, instead, from other factors. The aggregate data reported above illustrate two of them: the dramatic shift in the demographic structure and the rapid growth of the public pension system. As illustrated in Section 3 the latter has come about since 1972 through the extension of coverage to various groups with either very short contributive histories or with a very low contribution-to-pension ratio.

A third determinant of the system financial imbalance is the loss of contributions and the increase in pension payments induced by the shortening of professional lifes and the parallel growth of early retirement. In this study we try to document the extent to which this third factor may be "endogenous" to the SS system. We show that the Spanish SS legislation generates strong incentives to retire early and that Spanish workers tend to do so.

The rest of this paper is organized as follows. Section 2 presents some basic facts about labor market behavior and social insurance use of older workers in Spain. Section 3 describes the evolution of the Spanish system since its inception and illustrates in relative detail its current institutional features. Section 4 presents a set of simulations that illustrate the incentive effects of the current system upon labor market participation and retirement decisions. Section 5 offers some conclusions. Finally, Appendix A describes the main data sets used and other sources of information about retirement behavior in Spain, whereas Appendix B briefly reviews the recent literature about retirement in Spain. 


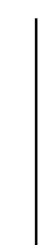


period 1964-75, and the number of workers affiliated to the SS system (en alta laboral) after 1979. The data for the period 1976-79 are not reported because they are considered to be of poor quality and fundamentally unreliable.

In 1964, only half of the workers were covered by mandatory insurance. Since then, the proportion covered has grown steadily. This is due mainly to the progressive integration into the SS system of a number of professional pensions schemes (Mutualidades), to the legislation of mandatory public pension for many categories of self-employed workers, and to the widening of coverage of the disability insurance plan. Historical details are provided in the next section.

Notice that the number of workers covered by SS has surpassed, in the most recent years, the official employment level. This provides strong support to the view that the EPA grossly underestimates the actual level of employment (and overestimates, consequently, the level of unemployment). For more details on this issue see, e.g. Villagarcia (1995).

Figure 5 shows the share of population aged $55+$ receiving old-age, disability, or some other type of pension. Data are again from the EPA, which asks respondents to report their status in the week before the survey, distinguishing between being retired, being permanently disabled, and receiving another pension different from old-age or disability. The latter category is particularly important for women, since it includes survivors' pensions. The upper profile indicates the fraction of older men receiving public pensions. The profile immediately below indicates the fraction of older men receiving old-age or survivors" pensions. The lower profiles correspond to females.

The figure shows clearly the steady increase in pension recipiency rates. The nature and the dynamics of the benefits, however, are quite different between the two sexes. Most men aged $55+$ receive old-age or disability pensions, whereas survivors' pensions are by far the most common type of benefit among women. 
In particular, for the years after 1986, for which a reliable comparison can be made, the growth rate of survivors' pensions among females greatly outpaces the growth rate of both old-age and disability pensions, the share of which remains rather stable at about 20 percent.

The difference between the two sexes in the relative importance of the various sources of pension income is readily understood by combining two factors. One is the increased coverage of males by means of old-age or disability pensions, the other is the longer life expectancy of females which transforms males' pensions into females' survivors benefits.

Although reliable estimates of replacement rates over time are not available, we were able to obtain some information using administrative records from SS. The old-age (OA) and disability (DI) pension replacement rates presented in Figure 6 are computed as the ratio between the initial pension award and the benefit base or base reguladora (defined in Section 3.4.3) at the time of retirement. Until 1985, the benefit base is a very good measure of pre-retirement earnings, being computed as the average salary over the last two years of work. After 1985 , it is computed over a longer period of eight years before retirement (see below).

Female old-age pension replacement rates surge to 100 percent in the early seventies. This is due to the fact that in the years immediately after the introduction of the current system, pensions were granted to individuals with very short work-histories and, simultaneously, pensions were adjusted to their minimum level. Replacement rates decline rapidly after 1979 as female wages move closer to those of men. After 1986, the female replacement rates become indeed lower than the male ones. In all other cases, the figure shows a steady decline of replacement rates over the period considered, which becomes more pronounced after the 1985 reform (see next section). Because of the way in which the initial 
pension is computed (see Section 3.3), this phenomenon suggests a continuous reduction in either the number of contributory years, or the age of retirement, or both. The existence of strong incentives to early retirement is, in our view, a critical feature of the Spanish SS system. We will come back to a detailed analysis of this issue in the last two sections of the paper. We will argue there that the main incentive to early retirement comes from the generous mechanism determining the minimum pension.

\subsection{Contemporaneous age patterns}

This section focuses on the age range from 45 to 75 . Unless indicated otherwise, the data are tabulations based on the pooled EPAs for the second quarters of the years $1993-95$.

These results are consistent with the ones obtained using the 1990-91 Household Budget Survey (Encuesta de Presupuestos Familiares or EPF), which we do not report.

Figure 7 compares cross-sectional LFPR by age for men and women. At age 45, female LFPR are less than 50 percent, about half the ones of men. After that age, LFPR decline steadily with noticeable differences between the two sexes. For women, LFPR decline linearly, with a sizeable jump only at age 65 . For men, the decline tends instead to accelerate with age, at least until age 65 , and shows two noticeable jumps at ages 60 and 65 .

Figures 8 and 9 show, for each age, the distribution by main activity (employed, unemployed, disabled and retired) separately by sex. Overall, the patterns of LFPR are confirmed but two interesting features appear, common to both men and women. First, the fraction of the population classified as unemployed declines rapidly with age. Second, the residual fraction of individuals not belonging to any of the previous four categories (not reported in the Fig- 
ures) increases steadily until age 65 when it suddenly falls. This downward jump is due to the award of non-contributory old-age pensions to people aged 65 who were previously out of the labor force or covered by other welfare programs (see below). After age 65, there are almost no men left in the residual category, whereas the fraction of women classified in this category declines due the increase in the fraction receiving survivors' pensions.

The next set of pictures are based on the Spanish household budget survey (Encuesta de Presupuestos Familiares, or EPF) for 1990. They are meant to assess the extent to which transfers from the SS system affect the income of older men and women.

Figure 10 shows the fraction of men that receive some form of public income at each age. Public income, identified in the EPF with welfare payments (prestaciones sociales), is broken down into three categories: old-age and survivors' (OAS) pensions, disability (Dl) pensions, and other welfare payments.

The fraction of men receiving disability pensions increases sharply right before age 65 , suggesting a strategic use of this kind of pensions to anticipate retirement and avoid the cuts that the legislation would otherwise impose on old-age pensions. In fact, those who are declared disable can stop working, collect a disability pension immediately, and still receive their old-age pension in full once they reach age 65 . For individuals that have already cumulated 35 years of work, are younger than 65 , belong to SS regimes that do not allow for early retirement and do not expect any substantial real wage increase, the "disabled first - retired later" strategy is clearly a dominant one.

A precise assessment of the number of those who participate to or receive income from private pension schemes is very hard to come by, due to the lack of data. Figure 11 reports data from the EPF and gives a breakdown of the sources of family income (earnings, assets, private pensions, and public transfers) by 
the age of the (male) family head. The graph suggests the irrelevance of private pensions. Notice that the fraction receiving such transfers, beside being almost negligible (less than 3 percent) for both men and women, remains practically constant at all ages.

\section{Institutional features of SS}

\subsection{Historical evolution}

Mandatory insurance for job related accidents was introduced in 1900 , through a bill that also authorized the creation of some funds, for public employees only, paying disability and retirement pensions.

In 1919, mandatory retirement insurance (Retiro Obrero Obligatorio) was introduced for private sector employees aged 16-65 whose total annual salary was below a certain threshold. Contributions to the fund came from both the employer and the employee in a 3 to 1 ratio.

In 1926, a universal pension system for public employees (Régimen de Clases Pasivas, or RCP) was established, providing a minimum pension and the option of contributing, out of the salary and up to a maximum amount, towards a complementary pension. By the late 1930s, most Spanish employees were covered, in one form or another, by some minimal, government mandated retirement insurance program.

With the end of the Republic and the advent of Franco's regime, a number of more or less connected changes were implemented. In 1939, Workers' Retirement (Retiro Obrero) was replaced by Old Age Insurance (Seguro de Vejez). While the former was based upon a capitalization system, the latter was from the beginning a completely unfunded pay-as-you-go scheme. At the same time, the regime promoted the creation of complementary pension funds, called $\mathrm{Mu}$ tualidades y Montepios Laborales, which were jointly managed by the Ministry 
of Labor and the regime-sponsored trade-unions.

By 1950, the system had acquired its basic organization in two pillars, which remained essentially unchanged until the mid 1970 s, when the collapse of the dictatorial regime brought about major changes. Public servants were all covered by the RCP, while private sector employees with annual earnings below a certain ceiling were covered by the Old Age Insurance. Both public and private employees could also en roll in complementary pension plans (the Mutualidades) which, despite the apparently private nature, were under complete government control.

Variability in benefit and tax rates across different professional groups and sectors of activity was not negligible. A ceiling on covered earnings was legislated in 1950 and updated more or less regularly after that. For most $\mathrm{Mu}$ tualidades, covered earnings were computed as the average annual salary over a period of 24 consecutive months chosen by the retiree within the last seven years of work.

\subsection{Major reforms since 1960}

The 1963 Social Security Act (Ley de Bases de la Seguridad Social) eliminated the income ceiling for enrollment in the Old Age Insurance, unified the various contributions for retirement, disability, etc., in a general SS contribution, and modified the percentages contributed by the employer and the employee.

Another consequence of the 1963 reform was the creation of a very large number of special funds (Regímenes Especiales) next to the general scheme (Régimen General), generating a jungle of special treatments and privileges for sectors and categories that were either politically close to the regime, or enjoyed the support of a particularly strong trade union.

The 1963 act also defined, for each professional group and sector of activity, 
the tax base (bases de cotización) upon which SS taxes were levied. Such tax base, however, had little to do with actual earnings. The difference between the two increased sharply over time until the 1972 reform, which effectively linked the tax base to wages (overtime pay excluded).

Besides linking the tax bases to actual wages, the 1972 bill also loosened significantly the eligibility criteria and began undoing the system of Mutualidades by establishing common replacement rates in place of the previous system where each category had its own. Finally, it established the principle that pensions should be indexed to both the cost of living and the real wage growth.

In 1977, a reform bill made a first attempt at harmonizing the many existing funds, by reducing the differences in the treatment they offered and by putting (in 1979) the administration of the whole system under the newly created $\mathrm{Na}$ tional Social Security Institute (Instituto Nacional de la Seguridad Social, or INSS). Overall, this process increased the percentage of workers covered by the public SS system, as it is clearly reflected by the aggregate data reported in the previous section.

The last major reform process, which came to shape the current regime, began in 1985. Three important changes were introduced. First, eligibility criteria for disability pensions were tightened. Second, the minimum number of years of contributions required to obtain an old-age pension was increased from 8 to 15 . Third, the number of years entering the computation of the benefit base was increased from 2 to 8 . The reform also provided for a reduction in the number of existing special funds, either through their integration in the genera] scheme or by merging them together. This process, which began in 1986, is not yet completed, as various small groups of public employees retain their privileges. Overall, the 1985 reform had more impact on the replacement rates than on the percentage of covered workers, as the latter had already reached a 
very high level.

In 1986, the Spanish Government established a public health insurance system (INSALUD) covering the whole population, which was largely financed by the contributions to the SS system. This arrangement ended with the budget year 1989, when the whole cost of INSALUD was attributed to the general Government budget. A set of regulations for complementary private pension plans was introduced in 1987, and further modified in 1995.

Another important change was the introduction, in 1990, of non-contributory pensions for elderly people aged $65+$ and for disabled people aged $18+$, who live in households with income below a certain minimum and satisfy a residency requirement. Financing of these non-contributory pensions is attributed to the general Government budget.

Finally on June 26, 1997, when this paper was already completed, the Parliament introduced a number of changes in the parameters to be used for the computation of benefit bases and pensions. The number of contributive years over which the benefit base is computed will progressively increase from the current 8 to 15 between now and 2001. The formula for the computation of the replacement rate $\alpha$ (see below) has also been made less generous, whereas the $8 \%$ per-year penalty applied to early retirees between the ages of 60 and 65 is reduced to $7 \%$ for those individuals with 40 or more contributive years at the time of retirement.

\subsection{The current situation}

Under the current legislation, public contributory pensions are provided by the following programs.

- "General Social Security Scheme" (Régimen General de la Seguridad Social. or RGSS) and "Special Social Security Schemes" (Regimenes Es- 
peciales de la Seguridad Social, or RESS): They cover all private sector employees, self-employed workers and professionals, members of cooperative firms, employees of most public administrations other than the central government (e.g. municipalities, local corporations), the clergy, convicted individuals working while in jail, professional athlets, members of the Parliament, and unemployed individuals who comply with the minimum number of contributory years when reaching 65 . The general and the special schemes together covered 12.4 million workers in 1996, of which 8.7 million (70 percent) were covered by RGSS and the remaining 3,7 million (30 percent) by the RESS. The latter include five special schemes set up for particular classes of workers:

1. Self-employed (Régimen Especial de Trabajadores Autónomos or RETA), covering 2,3 million workers on average during 1996.

2. Agricultural workers and small farmers (Régimen Especial Agrario or REA), covering about 1,2 million workers in 1996, of which 65 percent are employees and the remaining 35 percent are self-employed.

3. Domestic workers (Régimen Especial de Empleados de Hogar or REEH), covering 144 thousand individuals in 1996.

4. Sailors (Régimen Especial de Trabajadores del Mar or RETM), covering 82 thousand workers in 1996, of which 84 percent are employees and the remaining 16 percent are self-employed.

5. Coal miners (Régimen Especial de la Minería del Carbón or REMC), covering 28 thousand workers in 1996.

- Government employees scheme (Régimen de Clases Pasivas. or RCP): It includes public servants (both military and civil) currently employed by 
the central government and its local branches. It also covers, through a number of small special funds, all civil war veterans and survivors, a variety of semi-public employees, the victims of terrorist attacks, etc. The number of workers covered by RCP was 806 thousands in 1994 .

- "Special Funds": This is a family of special funds, remnants of the old Mutualidades y Montepios, paying small supplementary pensions and providing basic health insurance to certain groups of civil servants (MU. FACE), military personnel (ISFAS) and members of the judiciary system (MUCEJU). These pensions complement the basic ones paid by the RCP or by the RGSS.

- "Insurance Systems of Regional Governments and Local Administrations": These are small programs, covering employees of certain regional governments or local administrations, and are financed through transfers from the central government.

- Finally, there exists a long array of small pension plans, covering employees of other institutions (e.g. the Bank of Spain, a number of formerly public banks, many local corporations, special branches of some regional government, etc.), which managed to maintain their special treatments despite the process of homogenization started in the 1980s.

The legislation approved by Parliament on June 26, 1997 establishes the progressive elimination of all the special regimes by the year 2001. Aside from the pension scheme for public employees (RCP), the Spanish SS system will then be structured around only two "schemes" for the private sector: one for the employees and one for the self-employed. 
The number of workers affiliated to the general scheme increased from 6.7 million in 1982 to 8.7 million in 1996. As we have argued already, a large part of this growth simply reflects the progressive incorporation of a variety of previously autonomous funds. At the same time, the number of people affiliated to the special schemes decreased from 3.9 to 3.7 million. Overall, the number of people affiliated to SS (excluding RCP and the smaller funds) increased from 10.6 million in 1982 to the current 12.4 million.

Figure 12 shows the distribution of the affiliated to SS (excluding RCP) by program. The fraction affliated to the general scheme grew from about 63 percent in 1982 to about 70 percent in 1996, with a corresponding decline of the fraction affiliated to the special schemes. It is interesting to notice that all special schemes except the self-employed have lost affiliates. The decline has often been dramatic, as in the case of domestic workers and small farmers.

\subsection{The general scheme}

This section describes the rules governing old-age and survivors' pensions under the general scheme (RGSS), the main SS program in Spain and the benchmark for our simulations. Many of these rules also apply to the special schemes (RESS) and the scheme for government employees (RCP). The main differences will be noted below when we discuss these other programs.

\subsubsection{Financing}

RGSS is a pure pay-as-you-go scheme financed partly by contributions from earnings (about two thirds in 1996) and partly by transfers from the Government budget (about one third in 1996).

Contributions are a fixed proportion of covered earnings, defined as total earnings, excluding payments for overtime work, between a floor and a ceiling that vary by broadly defined professional category. Currently, eleven categories 
are distinguished. For the first seven of them, floors and ceilings apply to monthly earnings. These floors and ceilings are shown in Table 2 for the years 1990 and 1996. They are approximately equal to, respectively, the professional minimum wage and three times the professional minimum wage. For the last four categories, floors and ceilings apply to daily earnings and are not reported in the Table.

As the table shows, a process of slow convergence between floors and ceilings and across categories is in place. This process is generated by asymmetric inflation adjustments and an intentional effort to control total expenditures on pensions by slowing down the growth of the higher ones. Over time, these modifications have substantially weakened the link between covered earnings and lifetime wage and work effort, especially for workers earning relatively high wages and salaries.

SS tax rates have fluctuated over time, being lowered in the early 1980 s and increased afterwards. The current tax rate is 28.3 percent (it was 29.3 percent until January 1995), of which 23.6 percent is formally attributed to the employer and the remaining 4.7 percent to the employee. A tax rate of only 14 percent is levied on most earnings from overtime work, of which 12 percent is paid by the employer and the remaining 2 percent by the employee.

\subsubsection{Eligibility}

Entitlement to an old-age pension requires the number of years of contributions to be at least 15 (only 8 were required until 1985), of which at least 2 within the last 8 years immediately before retirement.

As a general rule, recipiency is conditional on having reached age 65 and is incompatible with income from any employment that requires affiliation to SS. 


\subsubsection{Benefit computation}

Suppose that the eligibility conditions are met and consider a person aged $65+$ who retires in month $t$ after $n \geq 15$ years of contributions. Its initial monthly pension $P_{t}$ is computed as

$$
P_{t}=\alpha_{n} \mathrm{BR}_{t}
$$

where the benefit base (base reguladona) $\mathrm{BR}_{t}$ is a weighted average of covered monthly earnings $W_{t-j}$ over a reference period that consists of the last 8 years before retirement

$$
\mathrm{BR}_{t}=\frac{1}{112}\left(\sum_{j=1}^{24} W_{t-j}+\sum_{j=25}^{96} W_{t-j} \frac{I_{t-25}}{I_{t-j}}\right)
$$

and $I_{t-j}$ is the consumer price index for the $j$-th month before retirement.

The replacement rate $\alpha_{n}$ depends on the number of years of contribution and is equal to

$$
\alpha_{n}= \begin{cases}0, & \text { if } n<15 \\ .6+.02(n-15), & \text { if } 15 \leq n<35 \\ 1, & \text { if } 35 \leq n\end{cases}
$$

It may be further adjusted in the case of early retirement as described in Section 3.4.4.

A few remarks are in order. First, after 15 years of contributions the pension is already equal to 60 percent of the benefit base. After 35 years of contributions the pension is equal to the benefit base and there is no direct advantage from contributing further, although contributions are mandatory until retirement.

Second, if there were no inflation and no wage growth in the reference period, that is, $W_{t-j}$ was constant over the last 8 years, then the benefit base would be equal to $6 / 7=.857$ of the last monthly social security wage. This is because pensions (and, usually, salaries) are paid in 14 monthly installments, whereas monthly social security contributions are levied on yearly salaries divided by 
12. For a person with 35 years of contributions, the annual benefit base would then be equal to the last annual wage.

Third, earnings in the last two years before retirement are not adjusted for inflation. For earlier months, they are adjusted and converted to money equivalents of the 25 -th month before retirement. In periods of high inflation, these aspects of the benefit formula imply that the benefit base may be well below the average real wage in the last 8 years.

Fourth, beginning July 15, 1997, the number of reference years will be increased by one every year until 2001 and could then be increased further up to 15 years. Moreover, the formula for computing $\alpha_{n}$ has also been changed to the following

$$
\alpha_{n}= \begin{cases}0, & \text { if } n<15 \\ .5+.03(n-15), & \text { if } 15 \leq n<25 \\ .8+.02(n-25), & \text { if } 25 \leq n<35 \\ 1, & \text { if } 35 \leq n .\end{cases}
$$

In all of our simulations we obviously used the old formula, which was in place over the relevant sample period.

\subsubsection{Early retirement}

The normal retirement age is 65 , but early retirement at age 60 is permitted for those who became affiliated to SS before 1967. Currently, more than one third of those who retire under the general scheme take advantage of this possibility.

The current legislation distinguishes between two cases. The first one, representing the vast majority of those currently retiring between age 60 and 65 [Duran (1995), p. 472], is the case of workers who started contributing as dependent employees to some Mutualidad Laboral before 1967, In this case, the replacement rate is reduced by 8 percentage points for each year under age 65 . Table 3 shows how replacement rates vary with age and the number of years of contribution. Notice the different incentive to work an extra year for a person 
aged 60 and one aged 65 , both with 34 years of contributions. In the former case, the pension increases from 56.8 to 68 percent of the benefit base, while in the latter it only increases from 98 to 100 percent. As of July 15, 1997 workers who retires after the age of 60 with 40 or more contributive years will be charged a penalty of only 7 percent for each year under age 65 .

The second case, representing about 10 percent of the early retirees, is the case of workers with dangerous or unhealthy jobs (e.g. bullfighters, employees of railroads, public transportation companies and airlines, etc.), or workers who were laid off for industrial restructuring regulated by special legislation. In this case, no reduction applies. Notice that these exemption rights are "portable", as the minimum retirement age without penalty, for an individual who was previously employed in one of the sectors deemed dangerous or unhealthy, is reduced in proportion to the number of years of work spent in such sectors.

Unless there are collective agreements that prescribe mandatory retirement, individuals may continue working after age 65 . There is no direct incentive for delaying retirement, however, at least for those individuals who have already reached 35 years of contribution at the age of 65 . The only indirect form of incentive would be the prospect of a particularly high wage growth in the forthcoming years, as this would proportionally increase the benefit base (recall that only the last 8 years of wages are taken into account in this computation). For those with less than 35 years of contribution, a small direct incentive to postpone retirement is provided by the fact that the ratio of the pension to the benefit base grows 2 percentage points per year of contribution until reaching 100 percent. 


\subsubsection{Maximum and minimum pension}

Pensions are subject to a ceiling legislated annually and roughly equal to the ceiling on covered earnings. The 1996 ceiling corresponds to about 4.3 times the minimum wage (salario minimo interprofesional, or SMI) and about 1.6 times the average monthly earnings in the manufacturing and service sectors. If the computed old-age pension is below a minimum, then a person is paid a minimum pension legislated annually. Minimum and maximum pensions, as well as the annualized SMI, are reported in Table 4 . Other things being equal, minimum pensions are higher for those who are older than 65 or have a dependent spouse.

In the last decade, minimum pensions grew at about the same rate as nominal wages, whereas maximum pensions grew at a lower rate that is about equal to the inflation rate. The ratio between the minimum old-age pension and the minimum wage has been increasing steadily from the late 1970s (it was 75 percent in 1975) until reaching almost 100 percent in the early 1990 s. On the other hand, the percentage of pensioners of the general scheme receiving the minimum pension has been declining steadily, from over 75 percent in the late 1970 s to 27 percent in 1995 .

In Figure 13 we analyze the relative importance of complements to the minimum, that is, the difference between the actual pension amount and the "virtual" pension in the absence of minimum pension rules. The sample, from administrative SS records as of January 1993, includes people who retired before 1985 with only 8 years of contributions.

The fraction of the total pension which comes from complements varies with the pension type. It is 10.1 percent for men and 12.5 percent for women in the case of old-age pensions, 5.8 and 6.2 percent respectively in the case of disability 
pensions, and 19.4 percent in the case of survivors' pensions. Not surprisingly, the fraction of pensioners who receive complements to the minimum and the share of the pension due to complements both decrease with the number of years of contribution. For example, people who retire with 10 years of contributions get 40 percent of their pension from complements, whereas people who retire with 35 years get less than 10 percent from complements.

It is interesting to note that both indices are higher for men than for women for longer contributory lives. This result has to be interpreted with care, however, since there are very few women (less than 10 percent) among pensioners who contributed for 35 years or more, whereas they represent the majority among pensioners who contributed for 15 years or less.

\subsubsection{Pension indexation}

Pensions are fully indexed to inflation, as measured by the Consumer Price Index (Indice de precios de consumo, or IPC). Until 1986, pensions were also indexed to real wage growth.

It should be noted that indexation is to expected inflation, as defined annually by the Central Bank and the Treasury. If actual inflation is above the expected one, then the difference is paid only to the pensions that are below the minimum wage. No adjustment is made, however, if actual inflation falls below the expected one, as it occurred during the last two years. Pensions that have already reached the legislated ceiling are not indexed but are automatically adjusted with the ceiling.

While this indexation mechanism could, at least theoretically, induce large reductions in the real value of higher pensions and a strong tendency to pension equalization, in practice this has occurred only to a limited extent. 


\subsubsection{Family considerations}

A pensioner receives a fixed annual allowance for each dependent child that is younger than 18 or disabled. In 1996 , this allowance was equal to 408,840 pesetas (pta), corresponding to about 45 percent of the annualized minimum wage. In addition, the minimum pension is increased by a fixed amount if a pensioner has a dependent spouse (Table 4).

Survivors (spouse, children, other relatives) may receive a fraction of the benefit base of the deceased if the latter was a pensioner or died before retirement after contributing for at least 500 days in the last 5 years. The benefit base is computed differently in the two cases. If the deceased was a pensioner,

the benefit base coincides with the pension. If the deceased was a worker, it is computed as an average of covered earnings over an uninterrupted period of 2 years chosen by the beneficiary among the last 7 years immediately before death. If death occurred because of a work accident or a professional illness, then the benefit base coincides with last earnings.

The surviving spouse gets 45 percent of the benefit base of the deceased. In case of divorce, the pension is divided between the various spouses according to the length of their marriage with the deceased. Such a pension is compatible with labor income and any other old-age or disability pension, but is lost if the spouse remarries. As a token of curiosity, we point out here that the remarriage rate among spanish widows is particularly low compared to other countries.

Surviving children get 20 percent each of the benefit base of the principal as long as they are less than 18 or unable to work, and stay unmarried. A full orphan who is a sole beneficiary may receive up to 65 percent of the benefit base. If there are several surviving children, the sum of the pensions to the surviving spouse (if any) and children cannot exceed 100 percent of the benefit 
base.

A Spanish peculiarity is the "pension in favor of family members". This pension entitles other surviving relatives (e.g. parents, grandparents, siblings, nephews, etc.) to 20 percent of the benefit base of the principal if they satisfy certain eligibility conditions (older than 45 , do not have a spouse, do not have other means of subsistence, have been living with and depending economically upon the deceased for the last two years). To this pension, one may add the 45 percent survivors' pension if there is no surviving spouse or eligible surviving children.

There are specific minimum pensions for the different types of survivorship. In particular, the minimum pension to a surviving spouse has been raised in 1992 and is now equal to the minimum old-age pension for a person without a dependent spouse.

\subsection{Special schemes}

In this section we sketch the main differences between the general and the special schemes. Whereas rules and regulations for sailors and coal miners are very similar to the ones for the general scheme, special rules apply to self-employed, farmers, agricultural workers, domestic servants, and a few other categories not discussed here, such as part-time workers, artists, traveling salespeople, and bullfighters. Beside differences in the SS tax rate and the definition of covered earnings, an important difference is the fact that the affiliated to the special schemes have no early retirement option (exception made for miners and sailors).

The rest of this section focuses on the special schemes for self-employed workers (RETA) and for farmers (REA), which together represent 93 percent of the affiliated to the special schemes and 86 percent of the pensions that they 
pay out.

\subsubsection{Self-employed}

While the SS tax rate is the same for the RETA and the general scheme (28.3 percent in 1996), covered earnings are computed differently, as the self-employed are essentially free to choose their covered earnings between a floor and a ceiling legislated annually. Not surprisingly in the light of the strong progressivity of Spanish personal income taxes, a suspiciously large proportion of self-employed workers report earnings equal to the legislated floor.

In 1996 , the floor and the ceiling were equal to 101,940 pta and 374,880 pta per month respectively, corresponding to 1.6 and 5.8 times the minimum wage, and .5 and 1.9 times the average earnings in manufacturing and services. For a self-employed aged $50+$, the ceiling was only about half, namely 195,000 pta per month, which was about equal to the average monthly earnings.

A crucial difference with respect to the general scheme is that, under the RETA, recipiency of an old-age pension is compatible with maintaining the selfemployed status. This provision effectively configures the RETA pensions as pure old-age pensions, completely independent from labor market participation decisions.

Some other important provisions are the following. RETA only requires at least 5 years of contribution in the 10 years immediately before the death of the principal in order to qualify for survivors' pensions. Under RETA, the latter is 50 percent of the benefit base. If the principal was not a pensioner at time of death, the benefit base is computed as the average of covered earnings over an uninterrupted period of 5 years chosen by the beneficiary among the last 10 years before the death of the principal. 


\subsubsection{Farmers}

In this case, both the SS tax rate and the covered earnings differ with respect to the general scheme. Self-employed farmers pay 18.75 percent of a tax base that is legislated annually and is unrelated to actual earnings. In 1996, this was equal to 80,490 pta per month, corresponding to 1.24 times the minimum wage and about 40 percent the average monthly earnings in the manufacturing and service sectors.

Farm employees, instead, pay 11.5 percent of a monthly base that depends on their professional category and is legislated yearly. In addition, for each day of work, their employer must pay 15.5 percent of a daily base that also varies by professional category and is legislated annually.

\subsection{Government employees}

We now describe briefly the main differences between the general scheme and the RCP, the pension fund for the employees of the central government.

Public servants are divided into 5 categories, labeled from $A$ to E, corresponding loosely to decreasing schooling levels: A for college graduates (doctor, licenciado, arquitecto o equivalente), B for people holding certain kinds of college diplomas (ingeniero técnico, diplomado, etc.), C for high school graduates (bachiller o equivalente), D for junior high school diplomas (graduado escolar o equivalente), and $\mathrm{E}$ for individuals with lower education levels (certificado de escolaridad). There were many more categories before the 1985 reform. For each of these categories, the budget law defines every year a theoretical SS wage (haber regulador) which is used to compute SS contributions and pensions. The implied wage scale has remained relatively constant since 1985 . So, for example, the ratio of level $\mathrm{A}$ to level $\mathrm{E}$ wages was equal to 2.39 between 1985 and 1989, dropped to 2.33 in 1990 , and rebounced and remained constant at 2.45 
afterwards.

SS contributions are the sum of three parts, each proportional to the legislated covered wage, according to proportionality factors legislated annually: a) derechos pasivos (3.86 percent in 1995), b) cuota mensual de Mutualidades (1.89 percent in 1995), and c) aportación del Estado (paid by the government, it varies between 6 and 10 percent depending on the sector of the administration).

To parallel this three-part contribution structure, actual pensions are computed by adding up three sources of benefits: a) the basic pension (derechos pasivos), b) a portion directed to the pensioner's family (ayuda familiar), and c) a complementary portion coming from the various Mutualidades (ISFAS, MUFACE, MUGEJU).

The basic monthly pension of a public servant who retires in month $t$ after contributing for $n$ years to RCP is computed as $P_{t}=\alpha_{n} \mathrm{BR}_{t}$, where the dependence of $\alpha_{n}$ upon the numbers of years worked has been changed quite frequently during the last 10 years. For $n \geq 15$, the last table of proportionality factors, legislated in 1990 , can be reasonably (but not exactly) approximated by

$$
\alpha_{n}=\min (1,1-.0366(35-n))
$$

The differences with respect to the general scheme are various. First, while the entitlement to a pension still requires at least 15 years of contributions, the replacement rate (the ratio of the pension to the benefit base) increases somewhat irregularly with seniority, up to 100 percent after 35 years. So, for example, 15 years of service give right to a pension equal to only 26.92 percent of the benefit base, against 60 percent of the general scheme. After 30 years the same ratio has increased to 81.73 percent, against 90 percent for the general scheme). Historically, this replacement ratio has been rather unstable as it can 
be modified year-by-year through the budget law.

Second, the benefit base is computed as a weighted average of covered earnings, upon which the worker paid the contributions, with weights equal to the percentage of the career spent at each level, that is,

$$
\mathrm{BR}_{t}=\sum_{i} p_{i} H_{i t}
$$

where $p_{i}$ is the fraction of the career spent on level $i$ and $H_{i t}$ are the covered earnings corresponding to level $i$, as determined by the current law at time $t$.

Third, unlike the general scheme, the RCP imposes mandatory retirement at age 65. Exception are made for a few special categories, such as university professors and judges. On the other hand, the RCP allows for early retirement at the age of 60 , without any penalty for public servants with at least 30 years of service (20 for military personnel).

A fourth important difference with respect to the general scheme is compatibility between RCP pensions recipiency and income from continuing to work. In a number of special cases, RCP pensioners are allowed to keep a public sector occupation, as long as this does not provide them with a "regular flow of income" (for example, this is the case of members of legislative bodies). More importantly, the legislation allows RCP pensions to be cumulated with earnings from employment in the private sector.

It should be noted that those who leave the public administration after contributing the minimum number of years but before reaching the retirement age, can claim an RCP pension once they reach age 65 . The benefit base used to compute such pension does not refer to the time when the individual left the public administration but is instead the one legislated for the year when they turn 65. Furthermore, any future modification in the law will have no impact upon the pensions which are already being paid. The latter will be forever 
regulated by the legislation of the time when the individual matured the right to the RCP pension.

When a public servant is dismissed because of disability (and therefore starts drawing a disability pension) or dies (and the survivors are therefore entitled to a pension), the missing years between the person's age at the time of the event and 65 are counted as actual years of service in the computation of either the disability or the survivors' pension. Should the disability be caused by an accident while on duty, the disability pension is doubled.

\subsection{Disability pensions}

The SS system provides insurance against both temporary and permanent illness or disability.

\subsubsection{Temporary illness or disability}

The subsidy for temporary illness or disability (incapacidad laboral transitoria) was not regulated by the 1985 reform, and its terms of provision have undergone frequent changes.

Eligibility requires affiliation to the SS system for a minimum period that depends upon the nature of the covered risk. Common illness requires only 180 days of contributions during the last 5 years, paid maternity/paternity leave requires at least 9 months before the date of delivery and 180 days during the last 12 months, whereas no minimum eligibility criterion is imposed for workrelated accidents or illnesses.

The benefit base depends on actual earnings during the last 12 months. In case of common illness or work-unrelated accident, the subsidy is equal to 60 percent of the benefit base for each day of absence between the 4-th and the 20 -th, and to 75 percent of the benefit base aftwerwards until the maximum period is reached. It is always equal to 75 percent in case of work-related 
accident or illness and in case of maternity/paternity (only one of the partners being allowed to use the subsidy per each child). The maximum period for which the subsidy can be received is 18 months, after which the worker has either to return to work or be classified as "permanently disabled".

\subsubsection{Contributive disability pensions}

Permanent disability pensions have played an important role in allowing Spanish workers to retire at ages earlier than 60 . In particular, they have been used extensively during the late 1970 s and early 1980 s as an early-retirement mechanism for workers in restructuring industries (shipbuilding, steel, mining, etc.), or as substitutes for long-term unemployment subsidies in depressed regions. The total disability rate (as a percentage of the workforce) doubled in less than ten years, from about 0.7 percent in 1975 to 1.5 percent in 1983 . The 1985 reform, by tightening the requirements, managed to bring the phenomenon under partial control. Disability rates have since decreased, stabilizing around 0.6 percent.

Disability pensions are distinguished into contributory and non-contributory. This section deals with the contributory pensions. The non-contributory ones are dealt with in the next section.

Eligibility and pension amounts depend on the level of disability. The 1985 reform distinguished four levels of permanent disability characterized by increasing severity. Since then, the legislation has formally reduced them to three, but has also created a special subcase of the first level with the explicit purpose of using the disability funds to subsidize the dismissal of old workers from certain sectors or geographic areas.

The first level (incapacidad permanente total para la profesión habitual, or IPT) corresponds to inability to do the usual job. A special subcase (incapaci- 
dad permanente total cualificada para la profesión habitual, or IPTC) applies only to employees older than 55 which are in particular socio-economic situations. The second level (incapacidad permanente absoluta, or IPA) corresponds to inability to do any kind of job. The third level (gran invalidez, or GI) requires, in addition, continued attendance by other persons in order to carry out the basic vital functions.

When disability is caused by an ordinary illness, eligibility to a pension requires from 5 to 15 years of contributions, depending on the age when the person fell ill and the seriousness of the disability. There is no contributive requirement when the disability is caused by an accident, whether or not workrelated, or a professional illness.

Eligibility requirements are fairly complicated. We try here to streamline their presentantion. In the cases of IPA or GI, 15 years of contributions are required, of which at least 3 during the last 10 years. For the other two cases (IPT and IPTC), eligibility depends on age. For persons aged 26 or younger, the requirement is half of the number of years between the age of 16 and the age when disability began. For persons older than 26 , the requirement is either 5 years or a fourth of the number of years between the age of 20 and the age when disability began, whichever is largest. Furthermore, at least a fifth of the required contributory years must have occurred during the last 10 years.

The benefit base depends on the source of disability. In case of ordinary illness, it is computed as for old-age pensions. For work-unrelated accident, it is the average annual wage over a period of 24 consecutive months chosen by the person within the last 7 years of work. For work-related accident or professional illness, it is the average wage in the last year of work.

The pension equals 55 percent of the benefit base under IPT, and increases to 75 percent under IPTC. In case of IPA. it is equal to 100 of the benefit base, 
whereas for GI it is equal to 100 percent of the benefit base plus another 50 percent covering the person taking care of the disabled.

Disability pensions are indexed to inflation like the other pensions of the RGSS. Unlike the latter, however, disability pensions may be kept while earning income from a job different from the one for which the disability (even a complete one) was determined.

We mentioned earlier that disability pensions were awarded very generously until 1985. This is illustrated in Figure 14, which reports the distribution of male disability pensions outstanding in 1993 , by age and year of award, based on administrative records from SS. For all age groups, awards peak between 1980 and 1982 , when the growth rate of the number of outstanding disability pensions reached 6 percent a year. Between 20 and 25 percent of the outstanding disability pensions were granted during those years which correspond to the most severe post-war recession in the Spanish economy. For women, a very similar picture is obtained.

The extent to which disability pensions may have been used as instruments to absorb the reduction of employment in certain sectors of the Spanish economy is evident in Table 5 which reports the percentage ratio between the number of disability pensions paid and the number of workers covered by the various SS programs for the years between 1981 and 1994.

While certain sectors are clearly characterized by a higher risk of work related accidents, this fact cannot explain the persistently higher percentage of disabled among the domestic or the agricultural workers, nor the strong countercyclical pattern of the disability ratios reported.

A second interesting element is the age distribution of the new recipients of disability pensions. In 1994, for example, the average age of new recipients was of 51.7 years on average. with a value of 50 for the RGSS and of $54,55.6$ 
and 57.9 respectively for RETA, REA and REEH. Table 6 shows, for each SS program and each level of disability, the fraction of new disability pensions awarded in 1994 to individuals aged 55+.

Criteria are now much stricter, although Court rulings often recognize claims to a pension that have been rejected by the SS administration. At least in principle, a person receiving a disability pension may be subject to periodic checks in order to determine whether the conditions for a pension are still met.

\subsubsection{Non-contributory disability pensions}

They are granted, through a special branch of the SS system called Instituto Nacional de Servicios Sociales (INSERSO), to disabled people aged 18 to 65 who are ineligible for contributory pensions, have been legal residents of Spain for at least 5 years (of which at least 2 immediately before applying for such pension), and whose annual income is below a certain threshold. INSERSO also provides its beneficiaries with basic health insurance, free medicines, and other complementary social services.

In 1990. a number of pre-existing non-contributory programs were rationalized and unified under INSERSO. As of 1995, the total annual budget of INSERSO was 418 billions pta, of which 64 percent were direct Government transfers while the rest was financed through SS contributions. Just to give an idea of the relative magnitude of this program, which represents about 0.7 percent of Spanish GDP, notice that total expenditures for the public university system in 1995 was only slightly higher, at about 0.9 percent of GDP.

Of the total annual budget of INSERSO in 1995, about 39 percent was spent either in direct monetary transfers or services to disabled individuals, about the same amount went to non-contributory old-age pensions (see next section), 20 percent was transferred to the regional governments (Comunidades 
Autónomas) providing similar services, and 2 percent covered INSERSO administrative costs.

The basic annual disability pension paid by INSERSO in 1996 was 498,120 pta, corresponding to 55 percent of the minimum wage (SMI) and 19 percent of average monthly earnings during the same year. Such amount may vary according to the economic and physical conditions of the individual and may be increased up to 50 percent.

At the end of 1995 , there were about 163 thousands recipients of noncontributory disability pensions residing in Spain, of which 36 percent were males and 64 percent females. Another 198 thousands people (22 percent males and 78 percent females) received one of three other monetary subsidies also administered by INSERSO.

\subsection{Other transfer programs}

We now describe a few other transfer programs that are either conditioned on age, or for which the elderly can qualify based solely on having low incomes.

\subsubsection{Unemployment benefits}

There exists a special subsidy for unemployed people that are older than 52 , lack income sources, have contributed to unemployment insurance for at least 6 years in their life and, except for age, satisfy all requirements for an old-age pension. This subsidy pays up to 75 percent of the minimum wage and may be received until the person reaches the age at which it can access an oldage pension. Years spent unemployed count as contributive years towards an old-age pension. 


\subsubsection{Non-contributory old-age pension}

A person aged $65+$ who does not qualify for an old-age pension, is entitled to a non-contributory pension (pension de jubilación no contributiva) if he/she has been a legal resident of Spain for the last 10 years and his/her annual income is below a certain threshold. This program is also administered by INSERSO. Recipiency of such a pension guarantees recipiency of public health care assistance and other benefits available to SS pensioners.

The annual pension amount is equal to the minimum income threshold and both depend on whether the person lives with others or not. If the person does not live with others, then the pension is equal to the basic amount paid out by INSERSO to disabled individuals. If the person lives with others, then the pension amount varies with the number of household members.

At the end of 1995,186 thousands people received a non-contributory oldage pension from INSERSO. Of these, 14 percent were males and 86 percent females.

\subsubsection{Other programs run by INSERSO}

In addition to its duties in the field of disability and old-age pensions, INSERSO runs a variety of other programs aimed at the elderly population. These programs include creating and maintaining residential and day-care centers open to retirees aged $60+$ and their spouses, and managing the "Social Thermal Program" (Programa de Termalismo Social) and the "Program for Elderly People's Holidays" (Programa de Vacaciones Tercera Edad). The latter two programs offer paid or subsidized vacations to pensioners or people aged $65+$, as well as

paid or subsidized stays at spas and thermal resorts within the country. The spouse of an eligible person is also covered by the program.

Recently; most regional governments have also begun to proride a number 
of services for retired people, from subsidized holidays to reduction in the cost of public transportation, special medical and psychological care, special houses for the elderly, etc.

\subsection{Private pensions}

Private pension coverage is voluntary but not very widespread. Yet, the number of participants to private pension plans has more than doubled in the last few years, from 628 thousands in 1990 to 1,525 thousands in 1994 [de las Fuentes and Gonzalo (1996), p. 255]. Assets of private pension funds still represent only a small but growing fraction of GDP, estimated to be 4.7 percent in 1997 [de las Fuentes and Gonzalo (1996), p. 251].

The main incentive to participation is tax deferral. Contributions can be entirely deducted from taxable income up to a maximum (equal to 1 million pta in 1996 , corresponding to 1.1 times the annualized minimum wage), provided that they do not exceed 15 percent of total annual income. Upon recipiency, pension benefits are treated as regular components of labor income and taxed accordingly.

There are three forms of organization of a private pension plan. The first (sistema asociado), open to all members of the association that promotes the plan (e.g. a trade union), is rather rare. The second (sistema de empleo), open to all employees of the firm that promotes the plan, is confined to a few large firms, mainly publicly owned, in the banking and electricity sectors. The third (sistema individual) is open to everybody and is the predominant one, covering about 85 percent of the participants to private pension plans.

\subsection{Rights of older workers}

Only public sector employees are subject to mandatory retirement. The mandatory retirement age is normally 65 , but it can be earlier for certain categories 
(military, police, etc.). There is no mandatory retirement in the private sector, unless it is specifically contemplated by collective agreements, which occurs rarely.

In principle, age discrimination is prohibited by the law. Indeed, a government attempt of introducing mandatory retirement at age 69 was rejected by the Spanish Supreme Court on the ground that it would represent a form of age discrimination that violates constitutional principles.

\section{Retirement incentives under the SS system}

We now present the results of calculations carried out to evaluate the retirement incentives provided by the Spanish SS system. These calculations refer only to the genera! scheme. We exclude disability insurance because of two reasons. First, it is now more severely screened than during the 1980 's. Second, the extent to which it is used as an early retirement device follows political criteria that vary greatly between regions and sectors and cannot be properly formalized. Private pensions are also excluded, since they are voluntary and only cover a very small fraction of the workforce.

Replacement rates are net of SS contributions and personal income taxes. Although there is no difference in the tax treatment of labor earnings and pensions, our simulations take into account the effects of the highly progressive nature of the Spanish tax system. This does not affect the qualitative picture, but it has a sizeable impact upon the final magnitudes. In order to provide the reader with a clearer picture of the powerful role that, over and above the pension system, a very progressive income tax schedule may play in determining labor supply decisions, we also report simulation results gross of income taxes for some of the most significant cases.

Exact calculations of the after-tax wealth and replacement rates are com- 
plicated by the fact that the number of bend points in the Spanish marginal tax schedule is high (34 in 1985 and still 17 in 1995). As an approximation, we proceeded as follows. We first used the 1995 tax schedule to trace out the relationship between average tax rate (net of standard deductions) and income (net of SS contributions paid by a worker). We then fitted by least squares a fourth-order polynomial to this relationship. Finally, the estimated coefficients were used to determine after-tax income for all previous and subsequent years.

\subsection{Base case}

Our base case is a male employee, born on January 1, 1930, who has been .contributing to SS without interruption since he turned 20, on January 1, 1950. He reaches the early retirement age of 60 in 1990 and the normal retirement age of 65 in 1995. He is married to a womant who is three year younger and never worked. They have no dependent children and their conditional survival probabilities at each age are equal to the ones obtained by the latest mortality tables published by the National Statistical Institute (INE) with reference to the year 1990. We assume that the survival probabilities of the husband and the wife are independent.

Our base-case worker has a real discount rate of 3 percent and his ageearnings profile has been constructed as follows. First, using the EPF for 1980-81, we computed median annual earnings in 1980 for a full-time, nonagricultural male employee born in 1930 . We then predicted annual earnings in all other years using the annual growth rate of nominal earnings, as computed by the INSS, After 1995, we assumed an annual growth rate of nominal wages of 4.5 percent and an annual inflation rate of 3 percent. These assumptions are in line with the main macroeconomic scenarios summarized in Herce (1997).

Simulations start in year 1985, when our base-case worker turns 55 and 
completes 35 years of contribution, and run for each year until he turns 70 , in year 2000. At age 55 , his benefit base is already equal to 100 percent of the average wage during the last eight years of work. For the period between 1985 and 1996, we use the historical data for all the relevant SS parameters. For the subsequent years, SS tax rates are assumed to remain constant at their 1996 level, the pension is assumed to be perfectly indexed to price inflation, whereas the floors and ceilings on earnings, as well as the minimum and maximum pensions, are assumed to grow at the same rate as nominal wages.

Our basic hypotheses are the following. First, if the worker stops working before age 60 , then he elects to begin receiving his old-age pension at age 60 , which is the earliest possible, whereas if he stops working past the age of 60 , then he starts receiving his old-age pension immediately. Second, if he stops working before age 60 , then he receives no benefits or unemployment compensations in the interim years until he starts drawing a pension. Third, the wealth calculations are all net present values as of January 1,1995 .

It may be worth summarizing the main qualitative effects of working one more year beyond age 60 in the simulations that we are about to present.

1. It may increase $\mathrm{SS}$ benefits by increasing the benefit base $B R_{t}$ or the replacement rate $\alpha_{n}$ (see Section 3.4 .3 ). The benefit base increases if earnings from the extra year of work exceed average earnings during the last 8 years. The replacement rate increases if the worker has contributed for less than 35 years, in which case an extra year of work buys an extra 2 percent of the benefit base. If the worker has already contributed for 35 years, as in the base case, only the effect on the benefit base is relevant.

2. It reduces the penalty for early retirement by 8 percentage points.

3. It reduces by one year the expected period over which the worker will 
receive a pension.

4. It implies paying additional SS contributions.

5. The marginal tax rate on labor income may turn out to be higher than the marginal tax rate on pension income, due to the high progressivity of the Spanish income tax schedule. This effect is likely to be important for workers that are in the higher portion of the earnings distribution.

Table 7 presents our calculations of replacement rates, SS wealth (SSW), SSW accrual (the changes in SSW with respect to one year earlier), SSW accrual rates (the rates of change in SSW), projected earnings, and the implicit tax/subsidy rates on continuing to work (minus the ratio between SSW accrual and projected earnings) at each age between 54 and 69. Both earnings and SSW wealth are net of personal income taxes and are expressed in thousands pta at 1995 prices.

SSW starts up at 11.3 million pta (about $\$ 87,000$ ), but it loses about 15 percent of its value between age 54 and age 59 because the growth of median wages during the period 1986-90 has not been enough to compensate for the additional contributions paid. SSW rises again between age 59 and age 63 , mainly because of the progressive reduction in the penalty for earlier retirement (effect (2)), but falls very rapidly after age 64 , when additional years of work add nothing to the expected pension amount while effects (3)-(4) become very strong. As a result of this, the implicit tax rate on continuing work increases rapidly between age 54 and age 58 , when it reaches 36 percent. It turns negative (subsidy) between ages 60 and 62 as the penalty associated to early retirement is progressively reduced. The net tax or subsidy is almost zero at age 63 , but becomes again positive (tax) and rapidly increasing afterwards.

Notice that the net replacement rate increases from about 60 percent at 
age 59 to about 100 percent at age 65 , and declines slightly afterwards. Also notice that SSW reaches its maximum value at age 54 , long before the worker is allowed to retire.

\subsection{Other cases}

Table 8 presents the incentive calculations for the case of a single worker. The main difference with respect to the base case is that the household he represents (missing a female spouse) has smaller effective survival probabilities at each age, resulting in a lower SSW. The age profile of tax/subsidy rates is not very different from the base case, except for the fact that there is hardly any subsidy for continuing work between age 60 and age 63 . In other words the reduction in the expected length of time over which pension benefits will be received (effect (3)) and the higher marginal tax rates on earnings completely wash out with the increase in the benefit base brought about by effects (1) and (2). Also in this case, SSW is maximized at age 54 .

Table 9 presents the incentive calculations for the case of a median wage profile with "incomplete" earnings history. This worker started working at age 30 , so that he does not fully qualify for a pension until he reaches age 65 in 1995. The high tax rate on continuing workg at all ages between 55 and 59 is counter-intuitive but it helps illustrating the dramatic importance of a sixth effect embedded in the Spanish SS system, the "minimum pension effect".

If the worker stops working at age 55 , with only 25 years of contributions, the pension that he will receive after turning 60 will be low and hit the lower bound on pensions when he reaches age 64 . Since minimum pensions grow at the same rate as nominal wages, there is no advantage in working one extra year in order to raise the initial pension, as the latter is in any case low and going to be equal to the minimum pension after just a few years. Notice that 
the situation is completely different if the worker considers retiring when he turns 60 . In this case, as shown in Table 3, working one extra year till age 61 would increase his pension from 54 to 62.6 percent of the benefit base.

Table 10 differs from the base case because we used the 10 th percentile of annual earnings as our 1980 anchor. Given the 1980 anchor, annual earnings for all other years are predicted as in the base case. Table 11 presents a parallel set of calculations using the 90 th percentile of annual earnings as our 1980 anchor. Tax/subsidy rates for these two cases are also presented in Figure 15 along with the base case.

We have already seen that the incentives to retire at the earliest possible date are much stronger for individuals with an incomplete earning history. The bias of the system toward "forcing out" low-wage earners is confirmed by the different patterns of the tax/subsidy rate faced by individuals at the 90 th and 10 th percentile of the wage distribution. Whereas for the former there is an incentive. stronger than for the base case, to keep working past 60 and until about the age of $63-64$, for the latter the disincentive to do so peaks at 60 , both in terms of accrual and tax/subsidy rates.

Figure 15 also shows that the tax rate for low-wage earners increases sharply in the 60-64 age range, contrary to what happens to high-wage earners. In other words, should a low-earnings individual be working at the age of, say, 61 , he would still find it advantegeous to quit immediately, whereas this is not true for the base case or a high-earnings person.

Table 12 provides the reader with a further appraisal of the extent to which the minimum-pension mechanism creates incentives to early retirement for lowwage earners. It reports tax/subsidy rates with and without minimum pensions in the base case, the incomplete earning history case and the 10th percentile case. 
The impact on the incentives to early retirement is very strong for the low-income individual. The variation caused by the minimum-pension on the implicit tax from continuing to work is already very high at the age of 55 it peaks at 60 and remains substantial also at much later ages. For a worker with incomplete earnings history the effect of the minimum-pension provision is also quite relevant until the age of 60 but vanishes rapidly afterwards. Instead the difference caused by the existence of the minimum pension on the tax/subsidy for the base case worker is always negligible.

\subsection{Discussion}

Our first concern is with the relationships between the incentives effects we have computed and the retirement facts available.

Figures 16 and 17 show hazard rates by age for men and women respectively. The hazard rate is defined here as minus the percentage change in the crosssectional age-participation profile. For men, the hazard increases smoothly with age and shows clear peaks at 60 and 65 corresponding, respectively, to the Spanish early and normal retirement ages. This is consistent with our calculations which show a strong incentive to retire either as early as possible (age 60) for low income earners and/or workers with incomplete histories and at 65 for everybody else.

Among women things are harder to judge. The behavior of the hazard rate for women is very herratic at almost all ages and there are various small peaks at ages between 52 and 61 , followed by the prominent one at age 65 . Our reading of the data is that the only significant peaks in the hazard for women occurs at ages 61 and 65 . All the other ones are likely to reflect pure sample noise, although one could rationalize the presence of a spike at age 54 through the interaction between eligibility requirements and minimum pension provisions. 
Next, we would like to verify if the recent trends in the patterns of retirement are also consistent with the structure of incentives we have derived. It is pointless to apply our calculations to years before 1985. In fact, due to the slow implementation of the 1985, reform only very recent years may reveal anything informative with respect to the working of the curren system.

Table 13 (based on SS administrative data) reports the distribution, according to the age of the pensioner, of the new retirement pensions awarded by the general scheme (RGSS) during the year 1991 and 1994. For workers aged 64 or less we also report the percentage of the new pensioners who, for the reasons detailed earlier, were exempted from the 8 percent penalty generally applicable for each year of early retirement.

The results are startling: in spite of the fairly heavy penalties associated with early retirement, more than 40 percent individuals retire at age 60 or earlier. Furthermore the percentage of those retiring earlier than 65 has been increasing steadily in the last few years, from 64 percent in 1991 to 70 percent in 1994. The intermediate years (not reported) are perfectly consistent with this trend.

Summing up: the Spanish SS system makes retirement at earlier ages than 65 the only rational strategy. Indeed, for workers with earning profiles below the median or with incomplete earning histories (a situation particularly frequent among women), the incentive to retire as early as possible, i.e. at age 60 , is particularly strong. The available data on hazard rates and the recent retirement patterns are completely consistent with this prediction.

\section{Conclusions}

The Spanish pension system has witnessed a remarkable evolution in the last 25 years. moving away from a collection of dispersed and uncoordinated profes- 
sional schemes toward a more uniform and comprehensive public system. Such process has generated a tumultuos growth in the size and nature of the public pension schemes, as well as a rapid increase in the number of retirees with short contributive histories receiving the minimum public pension. Together with the dramatic demographic changes affecting Spain since the late seventies, the continuos enlargement of the public pension system has been a major cause of the large financial imbalances which have come about in the last decade. This evolution is not yet completed and the recently enacted changes (June 1997) suggest that further razionalization and uniformization of treatments will be taking place between now and the beginning of the next century.

A third factor underlying the emergence of financial distress is the strong reduction in labor force participation rates among individuals aged 55-65, which began between 1975 and 1980 and is still taking place. This paper examines the interplay between the incentives generated by the public pension system and the decision to retire after the age of 55 . We quantify such incentives by computing measures of Social Security Wealth and of the implicit tax/subsidy to keep working, generated by the current system.

Our findings support the intuitive idea that pensions-induced incentives matter for the labor supply behavior of Spanish workers. While the Spanish system does not pay a particularly generous average pension relative to GDP per-capita, its "generosity" concentrates in providing relatively large minimum pensions to individuals with below average working histories and/or low wages. We show how this fact generates very strong incentives for this people to retire as soon as possible. At the same time, the pension system provides workers earning average or above average salaries and complete working histories, with relatively weak financial gains from not retiring after the age of 60 . These financial gains completely disappear and turn into losses around the age of 63. particularly for 
workers who have already reached 35 years of contributions. We have also shown how the disability insurance system is being used "strategically" by individuals who cannot legally anticipate retirement (e.g. self-employed and farmers) to actually achieve early retirement.

The combination of these three salient features of the Spanish legislation seems to account well for the observed increase in the percentage of early retirees among Spanish new pensioners during the nineties.

It should be stressed, though, that the possibility of retiring before the age of 65 is, according to current legislation, restricted to those workers who began their contributive lifes before 1967. While this group represents today the bulk of the labor force nearing the age of retirement, its quantitative relevance will be rapidly decreasing in future years.

It is yet unclear if such privilege will be progressively extended also to invididuals who began contributing after such date. Political pressure toward such extension is currently being exercised from various parts and the final outcome is hard to predict.

Legislation just enacted (June 26,1997 ) is ambivalent on this matter. On the one hand, it links more closely initial pensions to lifelong contributive histories, thereby starting to cut down on opportunities for "pension purchases" especially among self-employed. On the other, it mildly reduces the penalization for retiring younger than 65 for individuals with long contributive lifes and it leaves untouched both the disability and the minimum pension mechanisms, which we have singled out as the most powerful incentives for early retirement.

If anything, in fact, the extension from 8 to 15 of the number of years over which the benefit base is computed may have the effect of increasing the number of individuals for which the minimum pension is binding. As we have documented, workers expecting to receive a minimum pension have a strong 
incentive to anticipate retirement. The final outcome of the recent legislation may therefore be that of just increasing the proportion of the work force for which such incentive matters. 


\section{References}

Argimón, I., and J.M. González-Páramo (1987), "Translación e incidencia de las cotizaciones sociales por niveles de renta en España, 1980-84", Documentos de Trabajo, 1, Fundación FIES, Madrid.

Bandrés, E. and A. Cuenca (1996), "Capitalización y transferencias en las pensiones de la Seguridad Social" II Simposio sobre Igualdad, y Distribución de la Renta y la Riqueza, vol. 7, Fundación Argentaria, Madrid.

Barea, J. (ed.) (1995), El Sistema de Pensiones en España: Análisis y Propuestas para su Viabilidad, Circulo de Empresarios, Madrid.

Barea, J., and J.M. González-Páramo (eds.) (1996), Pensiones y Prestaciones por Desempleo, Fundación BBV, Bilbao.

Castellano. F. (1977), "Distribución por niveles de ingreso de la cuota patronal de la Seguridad Social en España", Investigaciones Economicas, 2, pp. 103-124.

de las Fuentes, J.M., and B. Gonzalo (1996), "Modelos de aseguramiento en España del riesgo de pérdida de la renta derivada de la actividad laboral a causa de la vejez", Documento de Trabajo, Serie Economía Pública, Fundación BBV, Bilbao.

Durán. A. (1995), "Politíca de pensiones: Situación y perspectivas", in SECOT, Las Actividades Económicas de la la Personas Mayores, Madrid.

Fernández Cordón. J.A. (1996), "Demografía, actividad y dependencia en España", Documento de Trabajo, Serie Economía Pública, Fundación BBV, Bilbao.

Herce. J.A. (1997), "La reforma de las pensiones en España: Aspectos analíticos y aplicados". Moneda y Crédito, forthcoming.

Herce, J. A.. and V. Pérez Díaz (eds.) (1995), La reforma del sistema público de pensiones en España, Colección de Estudios e Informes, 4, Servicio de Estudios de "La Caixa", Barcelona.

Herce, J.A., S. Sosvilla, S. Castillo, and R. Duce (1996), El Futuro de las Pensiones en España: Hacia un Sistema Mixto, Colección de Estudios e Informes, 8, Caja de Ahorros y Pensiones de Barcelona, Barcelona.

INVERCO (1996). Análisis de los sistemas de pensiones, Inverco-Towers Perrin. Madrid.

Jimeno, J.F.. and O. Licandro (1996), "El equilibrio financiero de un sistema de reparto de pensiones de jubilación: Una aplicación al caso español" Documento de Trabajo, 96-21. FEDEA, Madrid.

Martín. A.. and L. Moreno (1990), "Efectos de las pensiones de la Seguridad Social sobre la oferta de trabajo en España", Investigaciones Económicas, 14. pp. 291-303.

Medel. B., A. Molina, and J. Sánchez (1988), "Los efectos distributivos del gasto público en España", Documentos de Trabajo, 28, Fundación FIES, Madrid. 
Melis, F., and C. Díaz (1993), "La distribución personal de salarios y pensiones en las fuentes tributarias", I Simposio sobre Igualdad, etc., vol. II, Fundación Argentaria, Madrid.

Ministerio de Trabajo (1995), La Seguridad Social en el Umbral del Siglo XXI: Estudio Económico Actuarial, Madrid.

Monasterio, C., and J. Suárez (1992), "Gasto social en pensiones", Hacienda Publica Española, 120-121, pp. 119-143.

Piñera, J., A. Weinstein (1996), Una propuesta de reforma del sistema de pensiones en España, Circulo de Empresarios, Madrid.

Vereda, J., and F. Mochón (1978), "Efectos redistributivos de la Seguridad Social", Hacienda Pública Española, 52, pp. 83-93.

Villagarcía, T. (1995), "Esiste un sesgo de inactividad en la encuesta de población activa?", Documento de Trabajo, 95-04, Universidad Carlos III, Madrid. 


\section{A Data appendix}

In what follows we briefly describe the most important data sources employed in this chapter. We also mention some other potentially useful data sources.

\section{A.1 Microdata}

\section{A.1.1 Encuesta de Población Activa (EPA)}

This is a quarterly CPS-like survey of roughly 60,000 Spanish households carried out by the Spanish National Statistical Institute (INE). It contains fairly detailed information on labor force status, education and family background variables but, unfortunately, no information on wages and incomes. This feature is common to most European-style labor force surveys. Publicly released cross-sectional files are available from 1976.

From 1987, INE also releases the Encuesta de Población Activa Enlazada, which is the panel version of EPA obtained by exploiting the rotating crosssection nature of the survey. It contains fewer variables, but it permits to follow individuals for up to 6 quarters.

\section{A.1.2 Encuesta de Presupuestos Familiares (EPF)}

It is a cross-sectional household budget survey carried out by INE in 1973$74,1980-81$ and 1990-91, with reference to income and expenditure in the previous calendar year. The 1990-91 sample, used in this paper, contains 21,155 households and 72,123 persons.

\section{A.1.3 Administrative records from Social Security}

The third microdata set used in this paper is a random sample of 1 every 200 pensioners on file at the INSS on January 1993. The sample consists of 32,366 observations out of a universe of $6,473,200$ pensioners. The data proride information on initial and current pensions. The difference between these 
two concepts is broken down into revalorization and complement to minimum pension, which permits us to construct a measure of SS generosity.

\section{A.1.4 Other microdata}

Encuesta de Estructura Salarial: It was carried out by INE in 1995. It provides detailed information on wages, working hours and personal characteristics for about 175,000 workers in 19,000 establishments.

Encuesta Continua de Presupuestos Familiares: This is a rotating household survey carried out quarterly by INE since 1985. It collects data on income, consumption and personal characteristic for about 3,000 households. One eigth of the sample is replaced at each rotation.

\section{A.2 Aggregate annual or monthly data}

Boletín de Estadísticas Laborales: Published by the Ministry of Labor (MTSS), it contains data from 1981 on the most important SS programs.

Boletin Informativo de la SS: Published by the Dirección General de la SS, MTSS, it contains detailed information on social security expenditures, including medical care, from 1981.

Encuesta de Salarios en la Industria y los Servicios: It is a quarterly survey on wages and hours worked carried out by INE at the establishment level. 


\section{B Overview of the literature on SS and retirement in Spain}

We have been able to trace the existence of only one investigation of the impact of the Spanish SS system upon labour supply and, in particular, retirement decisions. Martín and Moreno (1990) look at weekly work hours over the period 1964-84 using net and gross SS wealth as explanatory variables. A fairly simple econometric analysis leads to the conclusion that the negative income effect associated to SS contributions more than compensate for both the susbstitution effect toward leisure and the increase in expected wealth induced by the promise of a pension payment, thereby increasing the overall labor supply.

The rest of the existing literature concentrates almost exclusively upon two issues:

1. The financial evolution of the system and the dramatic increase in its current account deficit as a consequence of both the system's generosity and the adverse demographic evolution.

2. The redistributive features of the system and, in particular, the existence of a wide dispersion in the internal rates of return across different programs.

\section{B.1 Analysis of the long-run sustainability}

Recent years have witnessed the publication of a large number of studies concerned with the long-run viability of the Spanish public pension system and with its capability to sustain the undergoing demographic changes. Among them are the monographs by Barea (1995), Barea et al. (1996), Herce et al. (1995), INVERCO (1996), Ministerio de Trabajo (1995), Piñera and Weinstein (1996), as well as the interesting papers by Herce (1997) and Jimeno and Licandro (1996). 
While the various authors reach different conclusions upon the type of reform which would result more appropriate, they pretty much express similar concerns about the economic viability of the existing system.

Normalizing at zero the deficit of the Social Security system in 1995, the estimates for 2010 range from -.8 to -3.5 percent of the GDP, with an average of -1.5 percent. For 2025 the average deficit prediction is of -2.6 with a range going from -1.0 to -4.2 percent of GDP. Most studies are based on a set of macroeconomic predictions that, while not exagerately optimistic, are nevertheless not obviously achievable. In general an average growth rate of GDP at 3 percent per year is assumed, together with a substantial increase in labor participation rates (up to 70 percent in 2010 ) and a reduction in the unemployment rate fromt he current 23 percent to about 16-18 percent. Barring substantial structural reforms these predictions are hardly realistic in the light of the performances of the Spanish economy over the last 20 years.

\section{B.2 Analysis of the redistributive effects}

Most studies concentrate upon the period prior to the 1978 reform and only a few are able to cover more recent years. The unit of investigation is always the individual agent, not the household, and income is very often measured as an annual flow and not as total lifetime income.

For the earlier period there is a widespread consensus on the regressive nature of the combined SS and fiscal system [see, e.g. Castellano (1977) and Vereda and Mochón (1978)]. The studies we have exhamined, though, are rather imprecise and naive in both their theoretical apparatus, the quality of the data available and the econometric techniques adopted. We find their conclusions rather dubious.

After 1978 things look quite different. While an early study [Argimón 
and González-Páramo (1987)] still finds evidence of a regressive effect in the structure of contributions, this is not the case when pension expenditures are taken into consideration [Medel et al. (1988)]. More recently a number of fairly complete studies [(Monasterio and Suárez (1992), Melis and Diaz (1993) and Bandrés and Cuenca (1996)] unequivocally document the very strong and progressive redistribution accomplished by the post-1978 and post-1985 Spanish pension systems.

These more recent studies do not restrict their analysis to annual income flows but manage to construct relatively credible indeces of life-time contributions and payments according to professional status and decile position in the overall distribution of earnings, and to compute internal rates of returns for different SS programs and income profiles.

Their, fairly uniform conclusions, can be summarized as follows:

- For most SS programs, both past and current contribution/payment profiles give rise to a rather large intergenerational transfer. For example, the ratio of net transfers to the total present value of pensions for individuals affiliated to the REEH went from 61.2 percent before the reform to 52 percent after (using a discount rate of 3 percent).

- The only important exception to this rule is given by the general scheme before and, especially, after the 1985 reform. In this case, the net lifetime SS wealth was positive (and equal to about 30 percent of total pension present value) before the reform, only if a real discount rate of 1 percent were used. It turned negative when a 3 percent discount rate was applied, and it remained negative in either cases after the reform. It turns out to be particuarly large ( 50 percent of total pension present value) when discounted at 3 percent. 
- Both the old and the current Spanish SS systems generate very large intragenerational transfers from the general to all the special schemes. Domestic workers and small farmers are by far the largest beneficiaries of such transfers.

- If one looks at the intragenerational transfers occurring not across programs but across income deciles, the Spanish SS system turns out to be a very progressive one: up to 90 percent of the total present value of pensions to which individuals in the first decile of the earnings distribution are entitled are a pure transfer. This transfer's percentage decrease rathers slowly as one moves up with earnings and changes sign only for the very last decile (or the last two, depending on details of the calculations). 
Table 1: Annual growth rates of real pension expenditures, number of pensions and real average pension (1994 prices), 1980-1995. Source: Ministerio de Trabajo (1995).

\begin{tabular}{|c|rrrrr|r|}
\hline & \multicolumn{5}{|c|}{ Type of pension } & Total \\
\cline { 2 - 6 } & Old-age & Disability & Widows & Orphans & Other rel. & \\
\hline Pension expenditures & & & & & & \\
$80-85$ & 5.5 & 9.3 & 4.6 & 3.2 & 4.9 & 6.4 \\
$85-90$ & 5.9 & 3.5 & 7.8 & 2.2 & 3.5 & 5.5 \\
$90-95$ & 5.8 & 3.9 & 6.3 & 1.4 & 6.3 & 5.3 \\
\hline Number of pensions & & & & & & \\
$80-85$ & 2.4 & 7.3 & 4.7 & 2.5 & 3.7 & 4.2 \\
$85-90$ & 2.9 & 1.6 & 4.0 & 1.0 & 3.0 & 2.8 \\
$90-95$ & 3.2 & 1.3 & 3.5 & .7 & 12.1 & 2.8 \\
\hline Average pension & & & & & & \\
$80-85$ & 1.8 & 1.3 & -.9 & .3 & -1.1 & 1.1 \\
$85-90$ & 2.7 & 2.3 & 3.7 & 1.4 & .9 & 2.6 \\
$90-95$ & 2.4 & 2.2 & 2.7 & .3 & -4.7 & 2.3 \\
\hline
\end{tabular}

Table 2: Floors and ceilings on monthly earnings (1000 pta. at current prices).

\begin{tabular}{|l|rr|rr|}
\hline \multirow{2}{*}{ Professional category } & \multicolumn{2}{|c|}{1990} & \multicolumn{2}{c|}{1996} \\
\cline { 2 - 5 } & floor & ceiling & floor & ceiling \\
\hline Engineers and college graduates & 87.150 & 291.540 & 113.070 & 374.880 \\
Technical engineers & 72.270 & 291.540 & 93.780 & 374.880 \\
Supervisors and foremen & 62.820 & 291.540 & 81.510 & 374.880 \\
Administrative assistant & 58.350 & 291.540 & 75.690 & 374.880 \\
Clerks & 58.350 & 185.820 & 75.690 & 279.390 \\
Janitors & 58.350 & 164.400 & 75.690 & 279.390 \\
Clerk Assistants & 58.350 & 164.400 & 75.690 & 279.390 \\
\hline
\end{tabular}

Table 3: Replacement rates by age and number of years of contribution.

\begin{tabular}{|c|rrrrrr|}
\hline \multirow{2}{*}{$\begin{array}{c}\text { Years of } \\
\text { contribution }\end{array}$} & \multicolumn{6}{|c|}{ Age } \\
\cline { 2 - 7 } & 60 & 61 & 62 & 63 & 64 & $65+$ \\
\hline 15 & .360 & .408 & .456 & .504 & .552 & .600 \\
20 & .420 & .476 & .532 & .588 & .644 & .700 \\
25 & .480 & .544 & .608 & .672 & .736 & .800 \\
30 & .540 & .612 & .684 & .756 & .828 & .900 \\
31 & .552 & .626 & .699 & .773 & .846 & .920 \\
32 & .564 & .639 & .714 & .790 & .865 & .940 \\
33 & .576 & .653 & .730 & .806 & .883 & .960 \\
34 & .588 & .666 & .745 & .823 & .902 & .980 \\
$35+$ & .600 & .680 & .760 & .840 & .920 & 1.000 \\
\hline
\end{tabular}


Table 4: Annualized minimum wage (SMI) and minimum and maximum annual pensions (1000 pta. at current prices).

\begin{tabular}{|c|c|cc|cc|c|}
\hline \multirow{3}{*}{ Year } & Annualized & \multicolumn{4}{|c|}{ Minimum pension } & Maximum \\
\cline { 3 - 6 } & SMI & & With dep. spouse & Without dep. spouse & pension \\
\cline { 3 - 6 } & & $<65$ & $\geq 65$ & $<65$ & $\geq 65$ & \\
\hline 1985 & 520.380 & 355.530 & 406.000 & 336.490 & 384.860 & 2631.300 \\
1986 & 561.960 & 399.000 & 455.840 & 364.000 & 417.200 & 2631.300 \\
1987 & 590.100 & 430.920 & 492.310 & 412.860 & 442.260 & 2631.300 \\
1988 & 616.560 & 465.500 & 532.000 & 411.040 & 471.100 & 2631.300 \\
1989 & 650.720 & 520.870 & 595.350 & 441.490 & 505.960 & 2710.400 \\
1990 & 700.140 & 575.820 & 658.140 & 488.040 & 559.300 & 2900.128 \\
1991 & 745.500 & 614.460 & 702.240 & 520.800 & 596.820 & 3094.448 \\
1992 & 787.920 & 649.530 & 742.280 & 550.550 & 630.840 & 3270.834 \\
1993 & 819.420 & 682.710 & 780.150 & 578.690 & 663.040 & 3437.644 \\
1994 & 847.980 & 712.810 & 814.520 & 604.170 & 692.230 & 3557.960 \\
1995 & 877.800 & 744.240 & 850.360 & 630.770 & 722.750 & 3714.508 \\
1996 & 908.880 & 770.350 & 880.180 & 652.890 & 748.090 & 3877.944 \\
\hline
\end{tabular}

Table 5: Percentage ratio between the number of disability pensions paid and the number of workers covered by the various SS programs, 1981-1994: General Fund (RGSS), self-employed (RETA), agricultural employees (REAa), farmers (REAb), coal miners (REMC), sailors (RETM), domestic workers (REEH).

\begin{tabular}{|r|rrrrrrr|r|}
\hline Year & RGSS & RETA & REAa & REAb & REMC & RETM & REEH & Total \\
\hline 1981 & .79 & 1.06 & 2.29 & 2.14 & 2.33 & - & 2.32 & 1.10 \\
1982 & 1.15 & 1.06 & 3.17 & 2.34 & 3.61 & - & 2.79 & 1.45 \\
1983 & 1.31 & 1.03 & 3.02 & 2.33 & 3.21 & - & 2.88 & 1.54 \\
1984 & 1.17 & .83 & 2.41 & 2.14 & 2.91 & - & 2.57 & 1.33 \\
1985 & .72 & .58 & 1.61 & 1.80 & 1.52 & - & 2.48 & .90 \\
1986 & .62 & .57 & 1.67 & 1.97 & 1.80 & 1.58 & 1.93 & .83 \\
1987 & .55 & .51 & 1.34 & 1.84 & 1.42 & 1.34 & 2.00 & .72 \\
1988 & .52 & .51 & 1.21 & 2.06 & 1.69 & 1.45 & 2.21 & .70 \\
1989 & $\mathbf{4 3}$ & .43 & 1.13 & 1.95 & 1.64 & 1.12 & 2.25 & .60 \\
1990 & .44 & .51 & 1.21 & 2.38 & 2.36 & 1.22 & 2.90 & 62 \\
1991 & .41 & .57 & 1.30 & 2.58 & 2.18 & 1.18 & 3.30 & .62 \\
1992 & .47 & .64 & 1.37 & 2.53 & 2.37 & 1.26 & 3.12 & .67 \\
1993 & .47 & .68 & 1.25 & 2.15 & 2.29 & 1.25 & 2.85 & .64 \\
1994 & .44 & .77 & 1.35 & 1.91 & 2.03 & 1.24 & 2.75 & .61 \\
\hline
\end{tabular}


Table 6: Fraction of new disability pensions awarded to individuals aged $55+$ by SS program and level of disability: Inability to do the usual job (IPT), inability to do any kind of job (IPA), complete inability (GI). Year 1994.

\begin{tabular}{|l|rrr|}
\hline Program & IPT & IPA & GI \\
\hline RGSS & $\mathbf{4 . 0}$ & 43.5 & 39.3 \\
RETA & 53.4 & 64.4 & 49.3 \\
REA & 58.5 & 63.7 & 68.9 \\
REMC & .3 & 48.6 & 60.0 \\
RETM & 14.9 & 32.1 & 32.0 \\
REEH & 25.0 & 75.0 & 80.6 \\
\hline
\end{tabular}

Table 7: Incentive calculations for base case. After-tax values in 1000 pta. at 1995 prices.

\begin{tabular}{|c|rrrrrr|}
\hline $\begin{array}{c}\text { Age at last } \\
\text { year of work }\end{array}$ & $\begin{array}{r}\text { Replacem. } \\
\text { rate }\end{array}$ & SSW & Accrual & $\begin{array}{r}\text { Accrual } \\
\text { rate }\end{array}$ & $\begin{array}{r}\text { Projected } \\
\text { earnings }\end{array}$ & $\begin{array}{c}\text { Tax/ } \\
\text { subsidy }\end{array}$ \\
\hline 54 & & 11343.7 &. &. & 1533.6 & \\
55 & & 11006.9 & -336.8 & -.030 & 1557.5 & .216 \\
56 &. & 10836.9 & -170.0 & -.015 & 1572.4 & .108 \\
57 &. & 10598.0 & -238.9 & -.022 & 1558.8 & .153 \\
58 & & 10025.0 & -573.1 & -.054 & 1582.3 & .362 \\
59 & .590 & 9566.8 & -458.2 & -.046 & 1603.8 & .286 \\
\hline 60 & .661 & 9809.7 & 242.9 & .025 & 1625.2 & -.149 \\
\hline 61 & .730 & 10008.0 & 198.3 & .020 & 1648.2 & -.120 \\
62 & .816 & 10193.3 & 185.3 & .019 & 1648.6 & -.112 \\
63 & .895 & 10117.1 & -76.2 & -.007 & 1649.4 & .046 \\
64 & .996 & 9860.6 & -256.5 & -.025 & 1606.9 & .160 \\
65 & .998 & 8629.4 & -1231.3 & -.125 & 1627.5 & .757 \\
66 & .996 & 7364.4 & -1264.9 & -.147 & 1648.4 & .767 \\
67 & .988 & 6067.9 & -1296.5 & -.176 & 1669.6 & .777 \\
68 & .981 & 4815.7 & -1252.2 & -.206 & 1691.0 & .741 \\
69 & .973 & 3608.2 & -1207.5 & -.251 & 1712.7 & .705 \\
\hline
\end{tabular}


Table 8: Incentive calculations for the case of a single worker. After-tax values in 1000 pta. at 1995 prices.

\begin{tabular}{|c|c|c|c|c|c|c|}
\hline $\begin{array}{l}\text { Age at last } \\
\text { year of work }\end{array}$ & $\begin{array}{r}\text { Replacem. } \\
\text { rate }\end{array}$ & SSW & Accrual & $\begin{array}{r}\text { Accrual } \\
\text { rate }\end{array}$ & $\begin{array}{r}\text { Projected } \\
\text { earnings }\end{array}$ & $\begin{array}{c}\text { Tax/ } \\
\text { subsidy }\end{array}$ \\
\hline$\overline{54}$ & . & 9159.8 & & & 1533.6 & \\
\hline 55 & . & 8847.4 & -312.4 & -034 & 1557.5 & .201 \\
\hline 56 & . & 8697.0 & -150.4 & -.017 & 1572.4 & .096 \\
\hline 57 & . & 8459.9 & -237.1 & -.027 & 1558.8 & .152 \\
\hline 58 & . & 7897.5 & -562.4 & -.066 & 1582.3 & .355 \\
\hline 59 & .590 & 7449.4 & -448.1 & -.057 & 1603.8 & .279 \\
\hline 60 & .661 & 7570.2 & 120.8 & .016 & 1625.2 & -.074 \\
\hline 61 & .730 & 7553.3 & -17.0 & -.002 & 1648.2 & .010 \\
\hline 62 & .816 & 7501.2 & -52.1 & -.007 & 1648.6 & .032 \\
\hline 63 & .895 & 7226.1 & -275.1 & -.037 & 1649.4 & .167 \\
\hline 64 & .996 & 6802.1 & -424.0 & -.059 & 1606.9 & .264 \\
\hline 65 & .998 & 5616.4 & -1185.7 & -.174 & 1627.5 & .729 \\
\hline 66 & .996 & 4421.8 & -1194.6 & -.213 & 1648.4 & .725 \\
\hline 67 & .988 & 3222.7 & -1199.1 & -.271 & 1669.6 & .718 \\
\hline 68 & .981 & 2078.4 & -1144.2 & -.355 & 1691.0 & .677 \\
\hline 69 & .973 & 989.5 & -1088.9 & -.524 & 1712.7 & .636 \\
\hline
\end{tabular}

Table 9: Incentive calculations for the case of incomplete earnings history. After-tax values in 1000 pta. at 1995 prices.

\begin{tabular}{|c|c|c|c|c|c|c|}
\hline $\begin{array}{l}\text { Age at last } \\
\text { year of work }\end{array}$ & $\begin{array}{r}\text { Replacem. } \\
\text { rate }\end{array}$ & SSW & Accrual & $\begin{array}{r}\text { Accrual } \\
\text { rate }\end{array}$ & $\begin{array}{r}\text { Projected } \\
\text { earnings }\end{array}$ & $\begin{array}{c}\text { Tax/ } \\
\text { subsidy }\end{array}$ \\
\hline 54 & & 10446.4 & & & 1533.6 & \\
\hline 55 & & 10022.4 & -424.0 & -.041 & 1557.5 & .272 \\
\hline 56 & . & 9664.3 & -358.1 & .036 & 1572.4 & .228 \\
\hline 57 & . & 9406.9 & -257.5 & .027 & 1558.8 & .165 \\
\hline 58 & & 9005.5 & -401.4 & .043 & 1582.3 & .254 \\
\hline 59 & .536 & 8687.4 & -318.1 & .035 & 1603.8 & .198 \\
\hline 60 & .613 & 8886.4 & 199.0 & .023 & 1625.2 & -.122 \\
\hline 61 & .691 & 9253.5 & 367.1 & .041 & $1648 . \overline{2}$ & -.223 \\
\hline 62 & .787 & 9670.8 & 417.3 & .045 & 1648.6 & -.253 \\
\hline 63 & .880 & 9851.4 & 180.6 & .019 & 1649.4 & -.109 \\
\hline 64 & .996 & 9860.6 & 9.3 & .000 & 1606.9 & -.006 \\
\hline 65 & .998 & 8629.4 & -1231.3 & -.125 & 1627.5 & .757 \\
\hline 66 & .996 & 7364.4 & -1264.9 & -.147 & 1648.4 & .767 \\
\hline 67 & .988 & 6067.9 & -1296.5 & -.176 & 1669.6 & .777 \\
\hline 68 & .981 & 4815.7 & -1252.2 & -.206 & 1691.0 & 741 \\
\hline 69 & .973 & 3608.2 & -1207.5 & -.251 & 1712.7 & .705 \\
\hline
\end{tabular}


Table 10: Incentive calculations for the 10 th percentile earnings case. After-tax values in $1000 \mathrm{pta}$. at 1995 prices.

\begin{tabular}{|c|rrrrrr|}
\hline $\begin{array}{c}\text { Age at last } \\
\text { year of work }\end{array}$ & $\begin{array}{r}\text { Replacem. } \\
\text { rate }\end{array}$ & SSW & Accrual & $\begin{array}{r}\text { Accrual } \\
\text { rate }\end{array}$ & $\begin{array}{r}\text { Projected } \\
\text { earnings }\end{array}$ & $\begin{array}{c}\text { Tax/ } \\
\text { subsidy }\end{array}$ \\
\hline 54 &. & 10621.0 &. &. & 889.8 &. \\
55 &. & 10334.2 & -286.9 & -.027 & 904.1 & .317 \\
56 &. & 10052.2 & -282.0 & -.027 & 913.1 & .309 \\
57 &. & 9776.9 & -275.2 & -.027 & 904.9 & .304 \\
58 &. & 9513.9 & -263.0 & -.027 & 919.0 & .286 \\
59 & .741 & 9255.8 & -258.1 & -.027 & 931.9 & .277 \\
\hline 60 & .731 & 8444.5 & -811.3 & -.088 & 944.8 & .859 \\
\hline 61 & .722 & 7659.2 & -785.3 & -.093 & 958.6 & .819 \\
62 & .810 & 6954.4 & -704.8 & -.092 & 958.9 & .735 \\
63 & .892 & 6431.7 & -522.7 & -.075 & 959.3 & .545 \\
64 & .996 & 6070.7 & -361.0 & -.056 & 933.8 & .387 \\
65 & .998 & 5342.6 & -728.1 & -.120 & 946.2 & .770 \\
66 & .996 & 4604.1 & -738.5 & -.138 & 958.8 & .770 \\
67 & .988 & 3855.8 & -748.4 & -.163 & 971.5 & .770 \\
68 & .980 & 3132.6 & -723.1 & -.188 & 984.4 & .735 \\
69 & .972 & 2435.9 & -696.7 & -.222 & 997.4 & .698 \\
\hline
\end{tabular}

Table 11: Incentive calculations for the 90 th percentile earnings case. After-tax values in $1000 \mathrm{pta}$. at 1995 prices.

\begin{tabular}{|c|rrrrrr|}
\hline $\begin{array}{c}\text { Age at last } \\
\text { year of work }\end{array}$ & $\begin{array}{r}\text { Replacem. } \\
\text { rate }\end{array}$ & SSW & Accrual & $\begin{array}{r}\text { Accrual } \\
\text { rate }\end{array}$ & $\begin{array}{r}\text { Projected } \\
\text { earnings }\end{array}$ & $\begin{array}{c}\text { Tax/ } \\
\text { subsidy }\end{array}$ \\
\hline 54 &. & 18450.0 & &. & 2561.6 &. \\
55 &. & 17800.3 & -649.7 & -.035 & 2603.0 & .250 \\
56 &. & 17427.6 & -372.7 & -.021 & 2630.5 & .142 \\
57 &. & 16829.3 & -598.3 & -.034 & 2610.5 & .229 \\
58 &. & 15565.3 & -1264.0 & -.075 & 2631.4 & .480 \\
59 & .561 & 14789.6 & -775.7 & -.050 & 2666.6 & .291 \\
\hline 60 & .627 & 15210.1 & 420.6 & .028 & 2701.7 & -.156 \\
\hline 61 & .691 & 15398.5 & 188.4 & .012 & 2739.6 & -.069 \\
62 & .776 & 15711.9 & 313.4 & .020 & 2740.2 & -.114 \\
63 & .859 & 15710.4 & -1.5 & -.000 & 2741.5 & .000 \\
64 & .966 & 15490.9 & -219.4 & -.014 & 2671.6 & .082 \\
65 & .982 & 13769.4 & -1721.5 & -.111 & 2705.6 & .636 \\
66 & .996 & 12002.4 & -1767.0 & -.128 & 2739.9 & .645 \\
67 & .988 & 9802.4 & -2200.0 & -.183 & 2774.7 & .793 \\
68 & .981 & 7677.5 & -2124.9 & -.217 & 2809.9 & .756 \\
69 & .973 & 5628.5 & -2049.0 & -.267 & 2845.6 & .720 \\
\hline
\end{tabular}


Table 12: Tax/subsidy rates with and without minimum pensions.

\begin{tabular}{|c|rr|rr|rr|}
\hline $\begin{array}{c}\text { Age at last } \\
\text { year of work }\end{array}$ & \multicolumn{2}{|c|}{ Base case } & \multicolumn{2}{c|}{ Incomplete history } & \multicolumn{2}{c|}{ loth percentile } \\
without & with & without & with & without \\
\hline 55 & .216 & .172 & .272 & .058 & .317 & .150 \\
56 & .108 & .050 & .228 & -.052 & .309 & .027 \\
57 & .153 & .123 & .165 & -.000 & .304 & .101 \\
58 & .362 & .372 & .254 & .217 & .286 & .355 \\
59 & .286 & .284 & .198 & .141 & .277 & .267 \\
\hline 60 & -.149 & -.221 & -.122 & -.331 & .859 & -.264 \\
\hline 61 & -.120 & -.127 & -.223 & -.256 & .819 & -.172 \\
62 & -.112 & -.112 & -.253 & -.254 & .735 & -.161 \\
63 & .046 & .046 & -.109 & -.109 & .545 & .001 \\
64 & .160 & .160 & -.006 & -.006 & .387 & .118 \\
65 & .757 & .757 & .757 & .757 & .770 & .738 \\
66 & .767 & .767 & .767 & .767 & .770 & .751 \\
67 & .777 & .777 & .777 & .777 & .770 & .762 \\
68 & .741 & .741 & .741 & .741 & .735 & .726 \\
69 & .705 & .705 & .705 & .705 & .698 & .691 \\
\hline
\end{tabular}

Table 13: Age-distribution of new pensioners, 1991 and 1994.

\begin{tabular}{|l|rrr|rrr|}
\hline & \multicolumn{3}{|c|}{1991} & \multicolumn{3}{c|}{1994} \\
\cline { 2 - 7 } Age & Penalty & No Penalty & Total & Penalty & No Penalty & Total \\
\hline$\leq 60$ & 38.61 & 1.81 & 40.42 & 37.84 & 2.89 & 40.73 \\
61 & 5.91 & .32 & 6.23 & 7.20 & .34 & 7.54 \\
62 & 5.72 & .27 & 6.00 & 7.39 & .35 & 7.74 \\
63 & 4.71 & .51 & 5.22 & 6.13 & .34 & 6.46 \\
64 & 4.22 & 1.83 & 6.04 & 5.22 & 2.25 & 7.47 \\
65 & - & - & 31.38 & - & - & 26.39 \\
66 & - & - & 1.71 & - & - & 1.17 \\
67 & - & - & .93 & - & - & .72 \\
68 & - & - & .58 & - & - & .50 \\
69 & - & - & .41 & - & - & .39 \\
$\geq 70$ & - & - & 1.07 & - & - & .89 \\
\hline$<65$ & 59.17 & 4.74 & 63.92 & 63.79 & 6.16 & 69.95 \\
$\geq 65$ & - & - & 36.08 & - & - & 30.05 \\
\hline
\end{tabular}




\section{List of Figures Legends}

Figure 1:

Age structure of the population of working age $(16+)$ by sex and year.

Figure 2:

Historical trends in labor force participation of older men.

Figure 3:

Historical trends in labor force participation of older women.

Figure 4:

Fraction of workers covered by the SS system.

Figure 5:

Old-age and survivors' (OAS) and disability (DI) pension recipiency among people aged $55+$.

Figure 6:

Replacement rates.

Figure 7:

Participation rates by age and sex.

Figure 8:

Distribution of activities of men by age.

Figure 9:

Distribution of activities of women by age.

Figure 10:

Public income recipiency by age for men.

Figure 11:

Distribution of family income by source.

Figure 12:

Distribution of affliated to SS by program: General scheme (RGSS), self-employed (RETA), agricultural workers and small farmers (REA), domestic workers (REEH). Annual averages 1982-1996.

Figure 13:

Fraction of pensioners receiving complements to the minimum and share of the pension due to complements by number of years of contribution, 1993.

Figure 14:

Distribution of male disability pensions outstanding in 1999 by age group and year of award. 
Figure 15:

Tax/subsidy rates across earnings profiles.

Figure 16:

Hazard rate out of the labor force for men.

Figure 17:

Hazard rate out of the labor force for women. 
Figure 1: Age structure of the population of working age (16+) by sex and year.

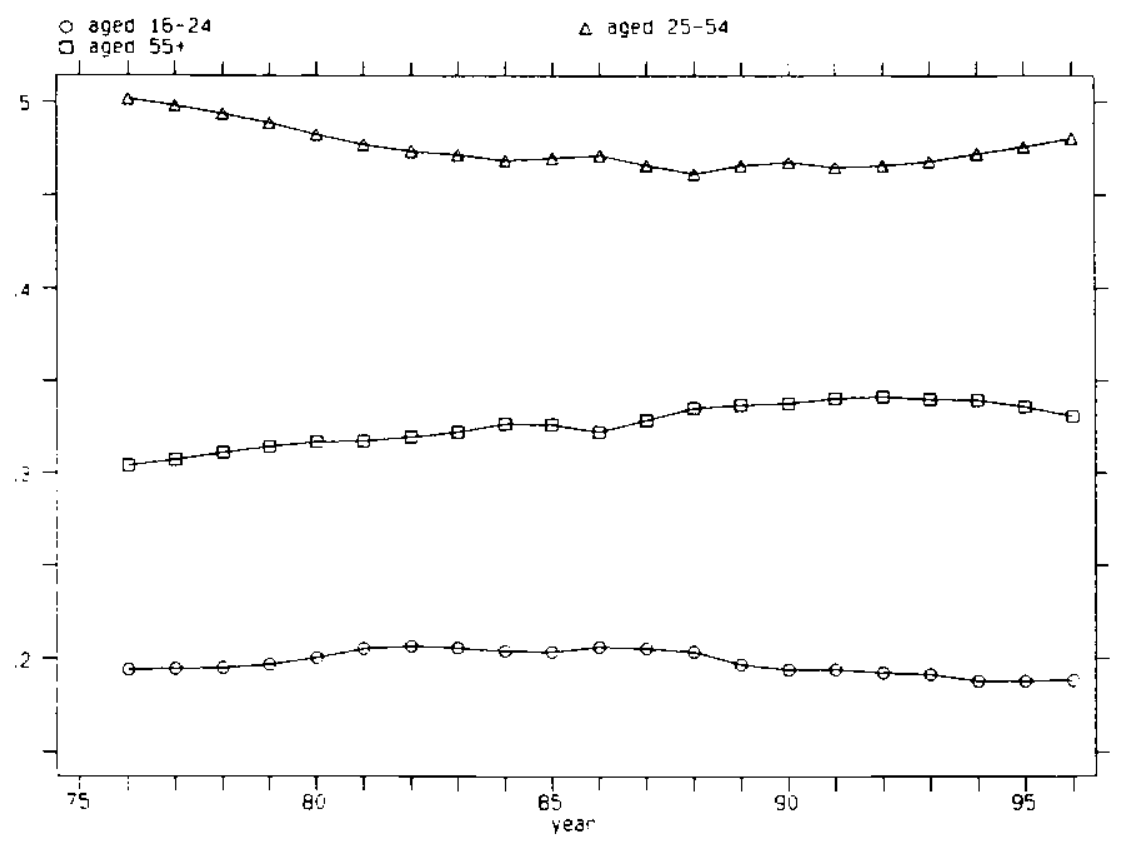


Figure 2: Historical trends in labor force participation of older men.

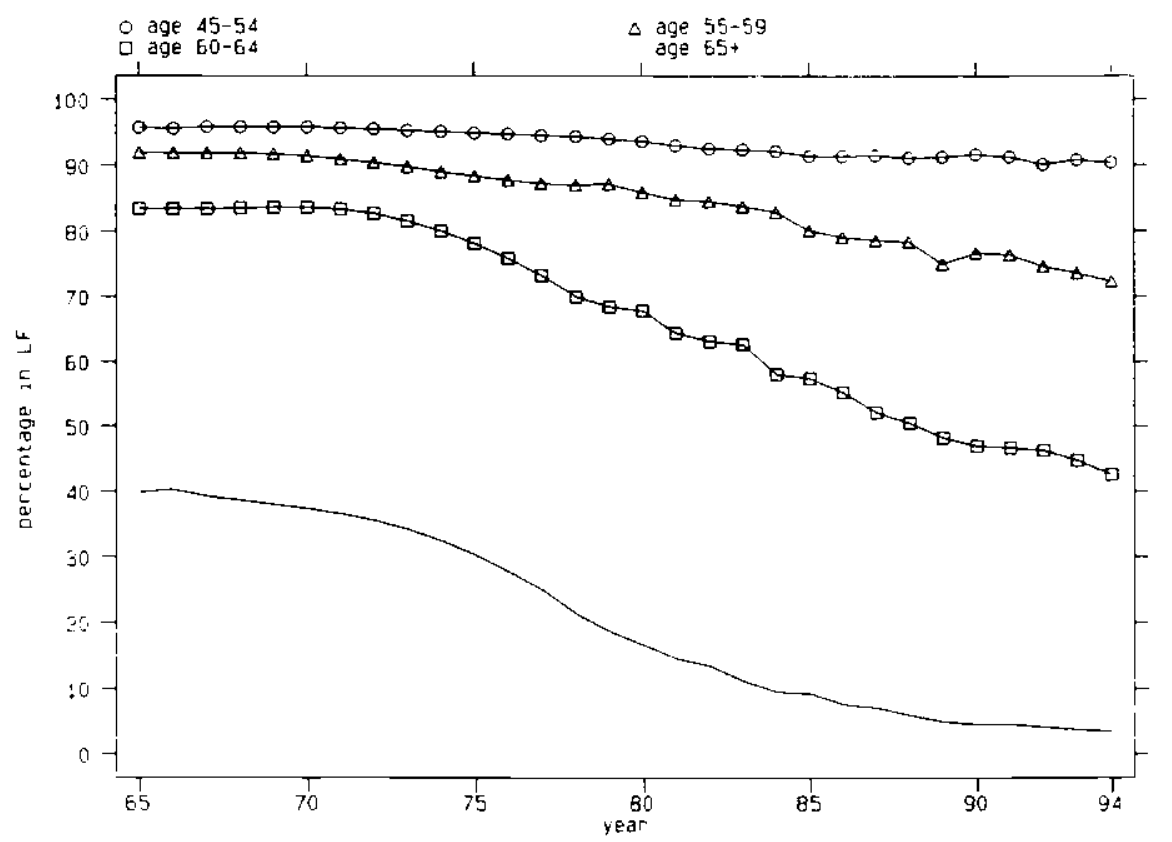


Figure 3: Historiual trends in labor force participation of older women

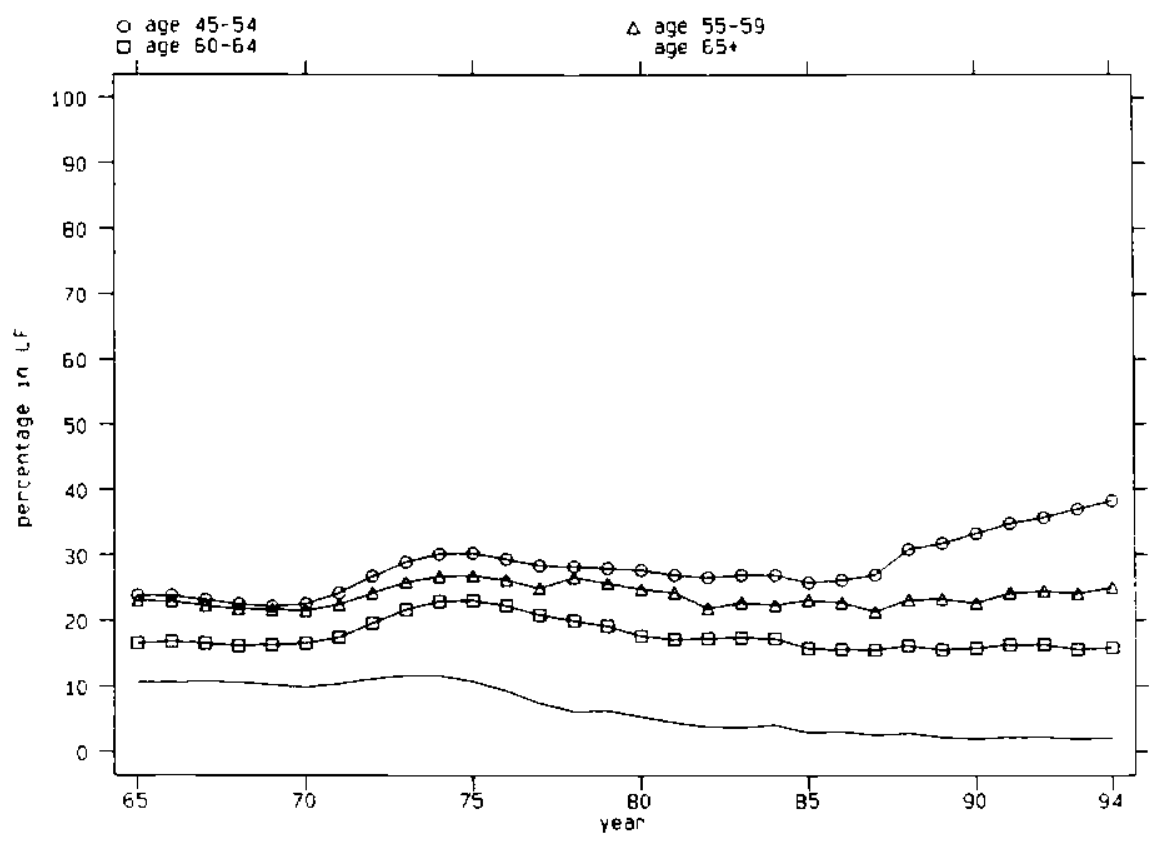


Figure 4: Fraction of workers covered by the SS system.

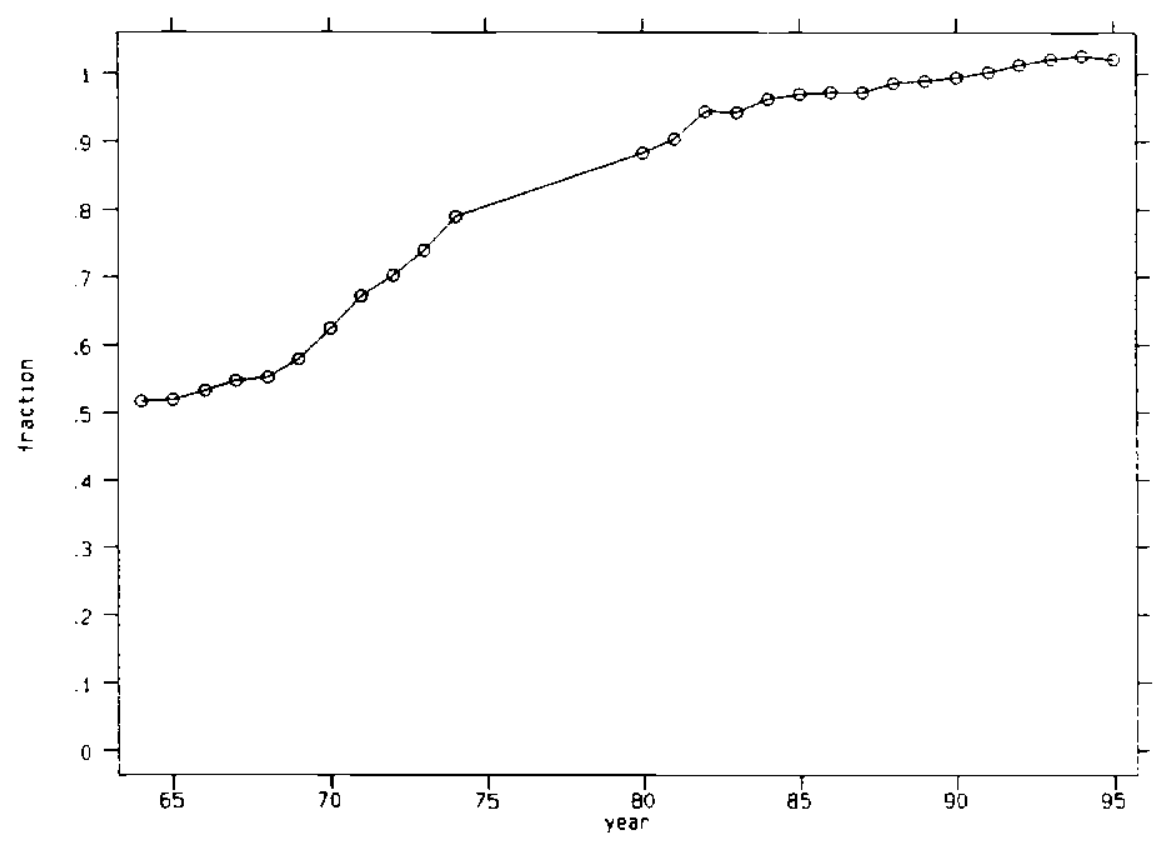


Figure 5: Old-age and survivors' (OAS) and disability (DI) pension recipiency among people aged $55+$.

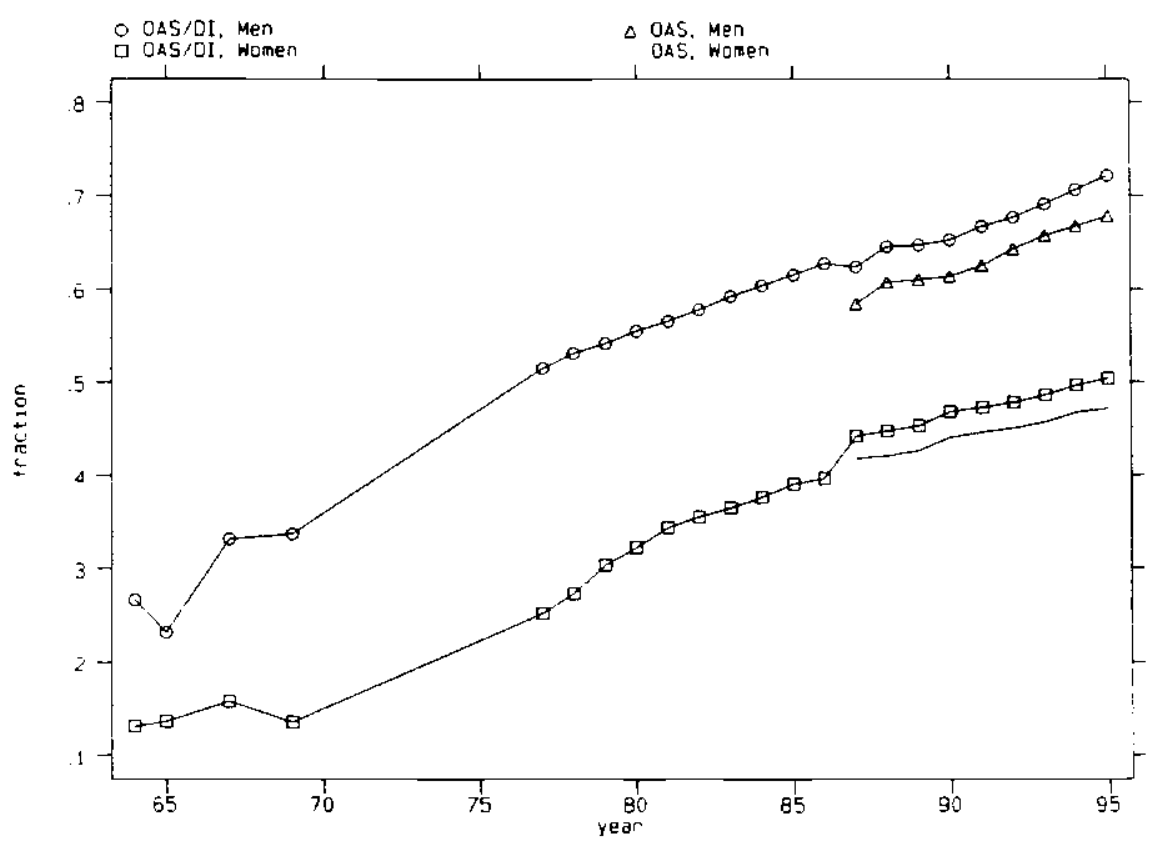


Figure 6: Replacement rates.

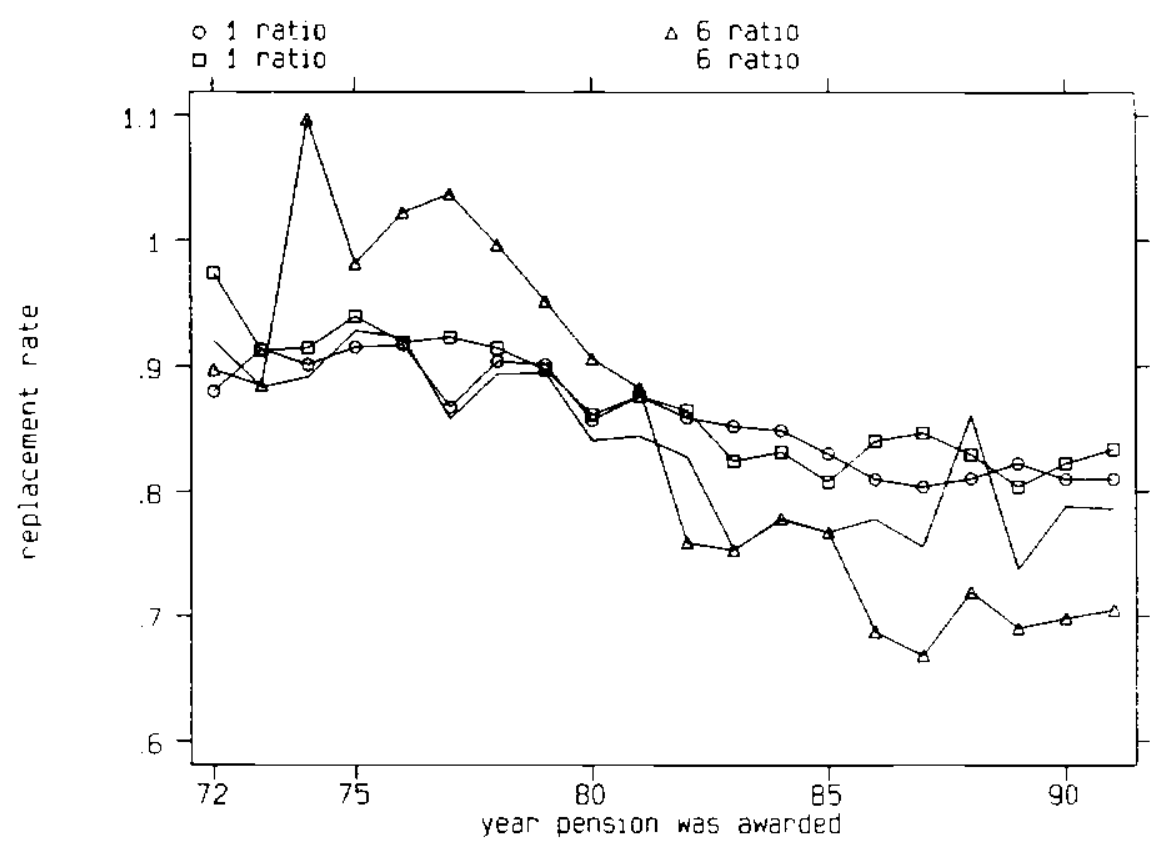


Figure 7: Participation rates by age and sex.

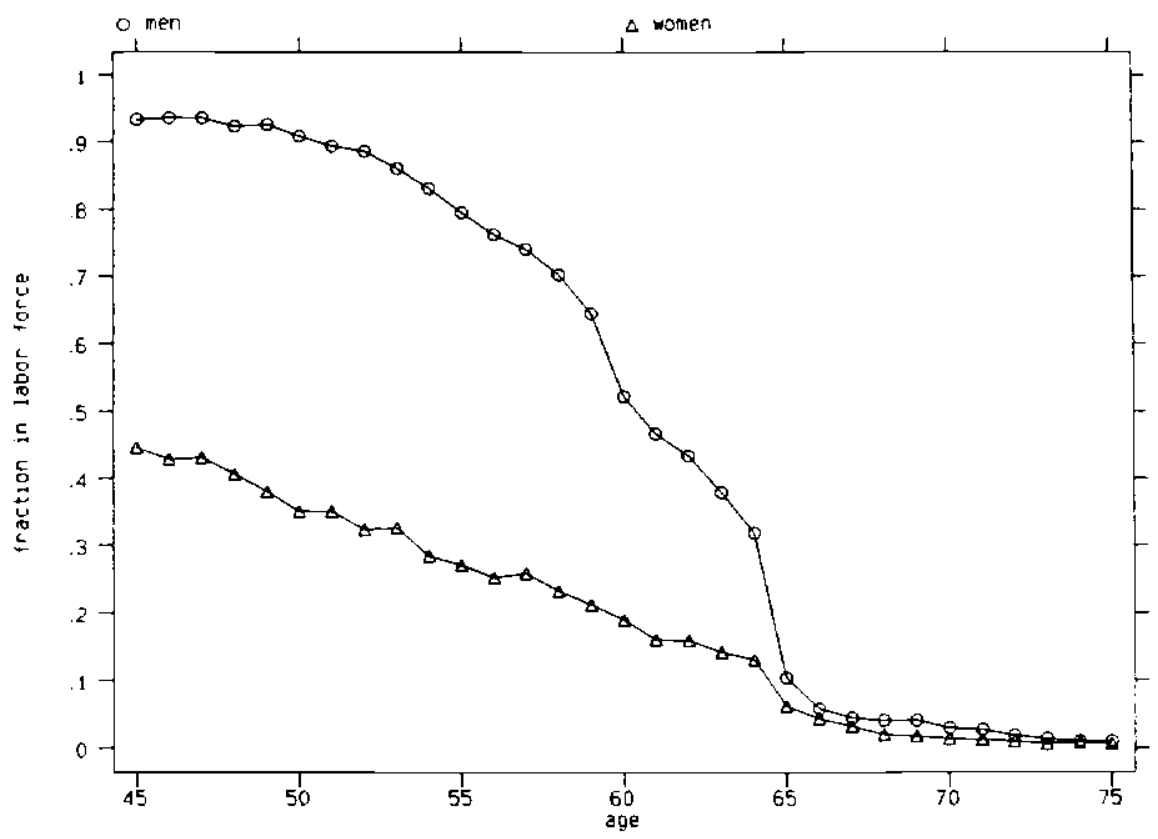


Figure 8: Distribution of activities of men by age.

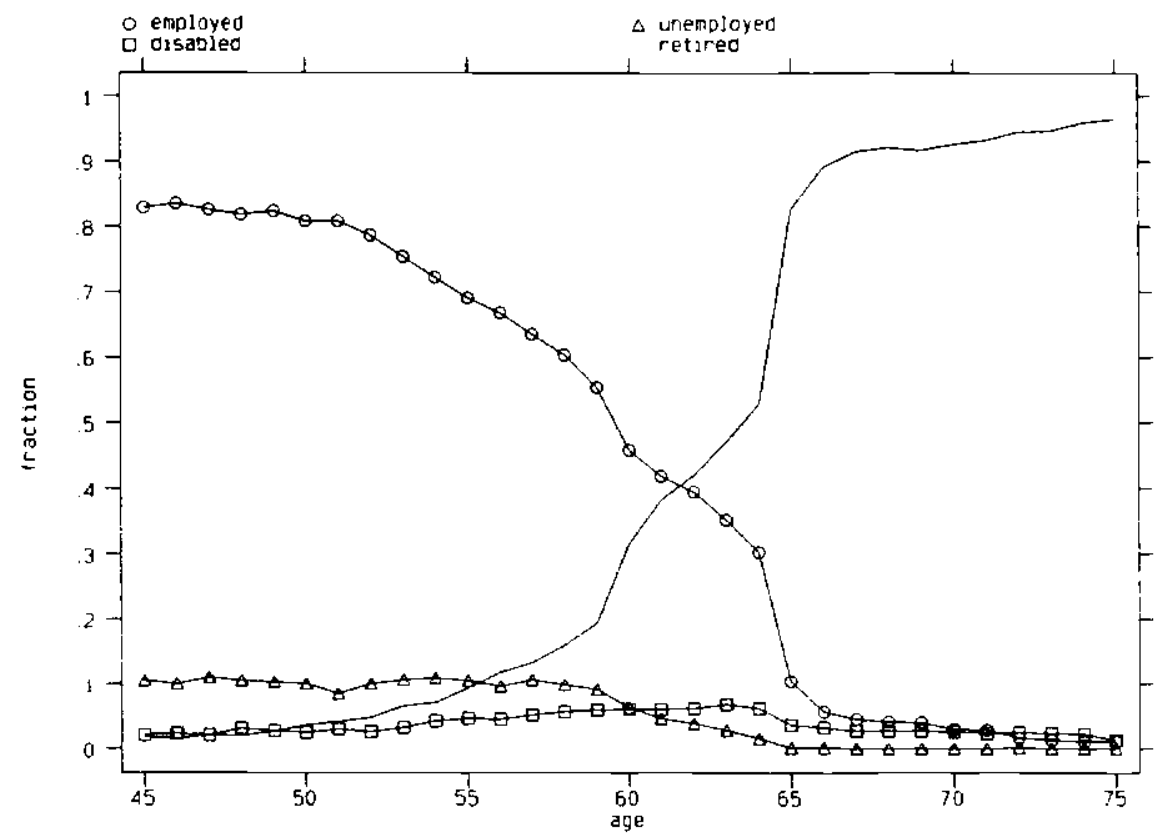


Figure 9: Distribution of activities of women by age.

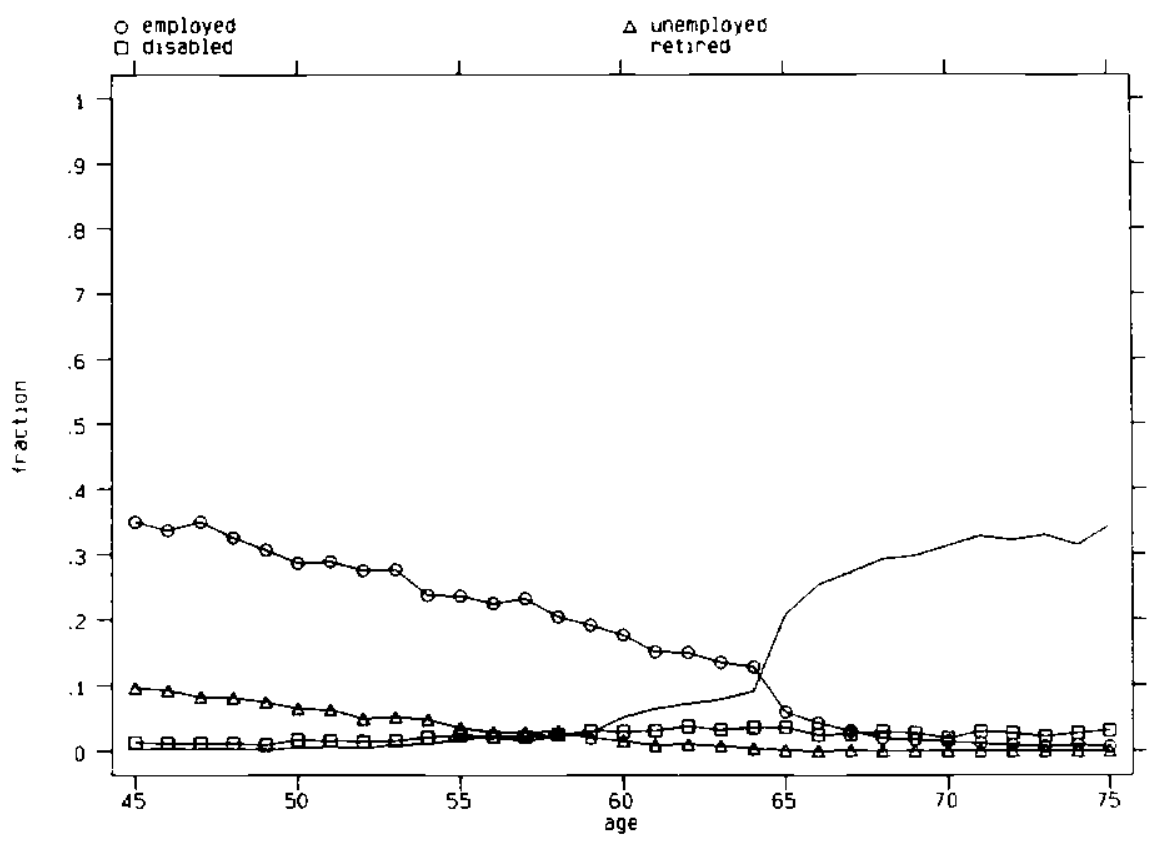


Figure 10: Public income recipiency by age for men.

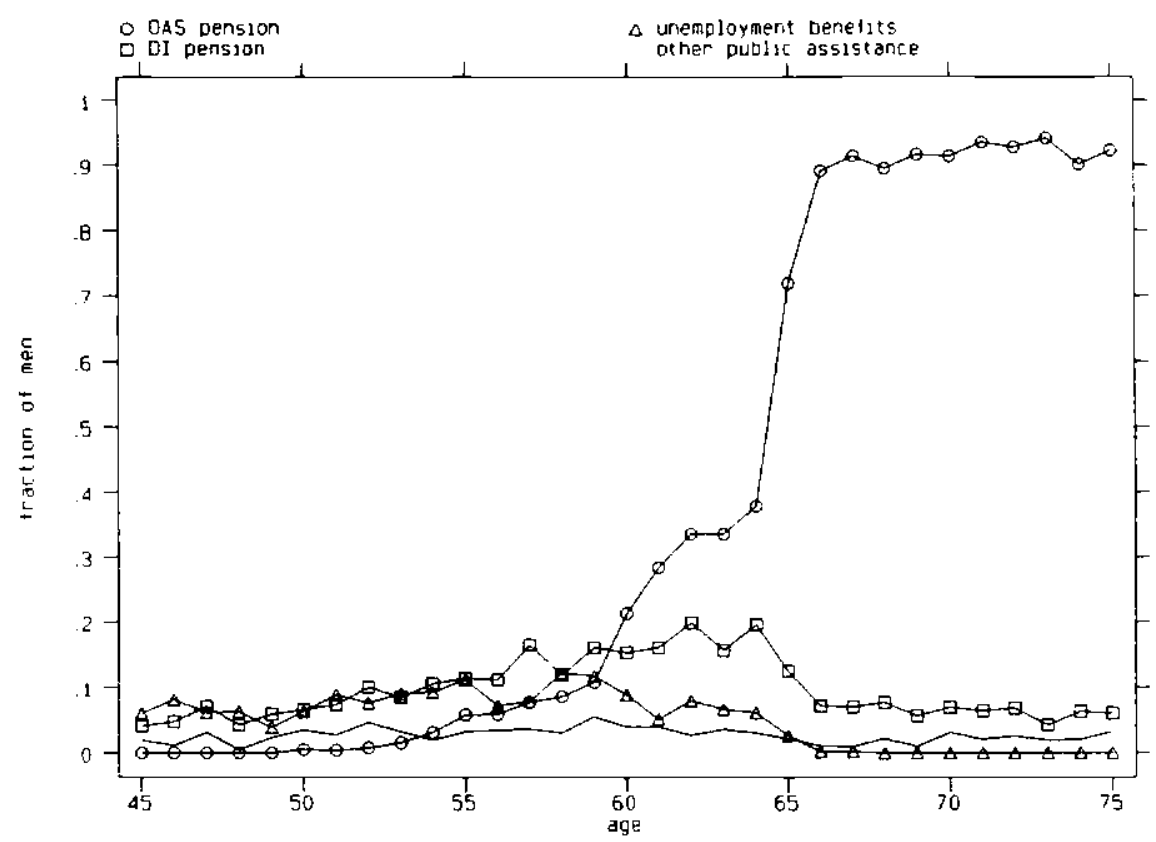


Figure 11: Distribution of family income by source.

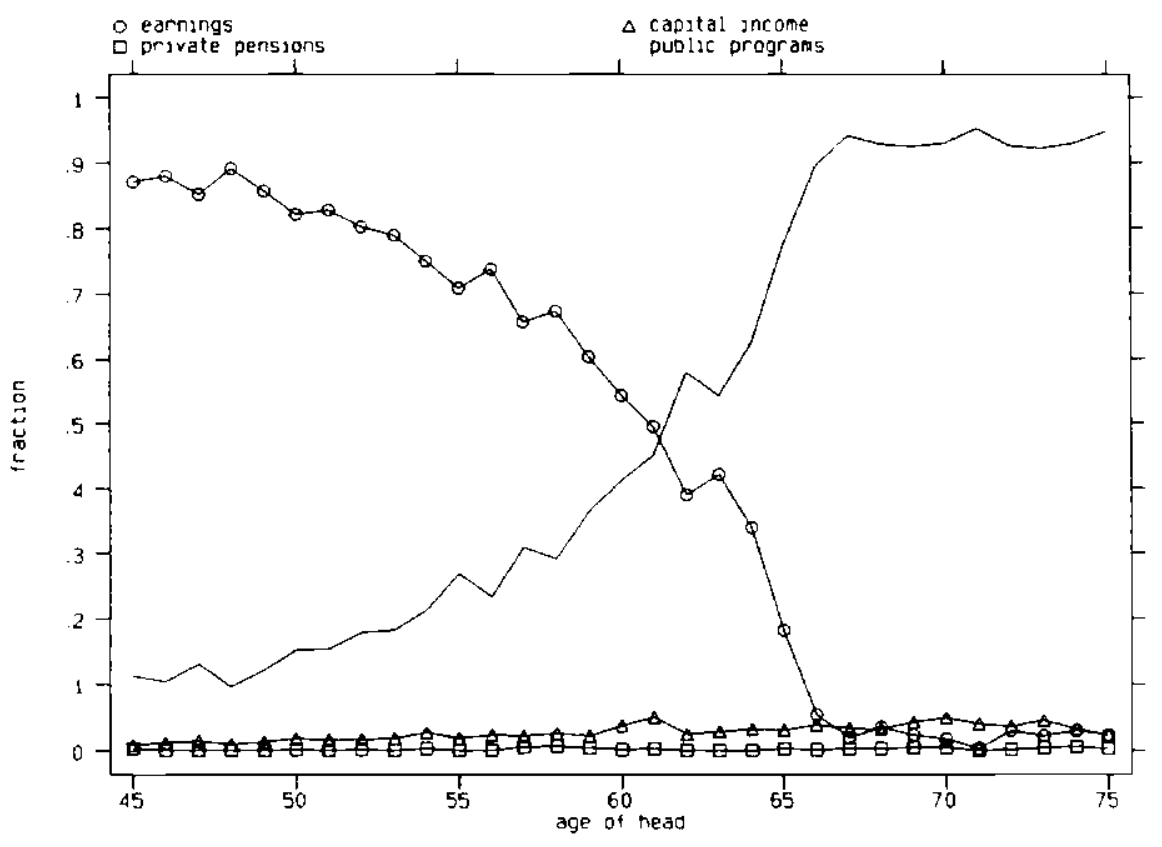


Figure 12: Distribution of affiliated to SS by program: General scheme (RGSS), self-employed (RETA), agricultural workers and small farmers (REA), domestic workers (REEH). Annual averages 1982-1996.

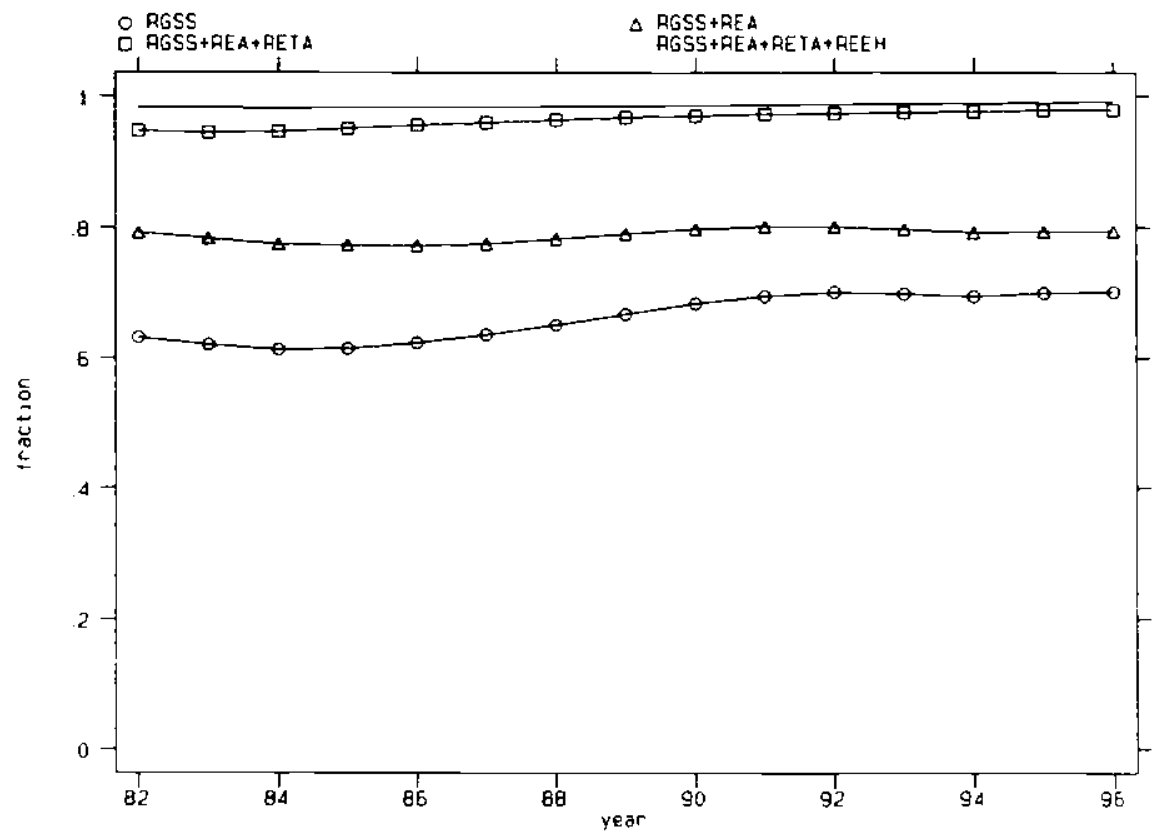


Figure 13: Fraction if pensioners receiving complements to the minimum and share of the pension due to complements by number of years of contribution, 1993.

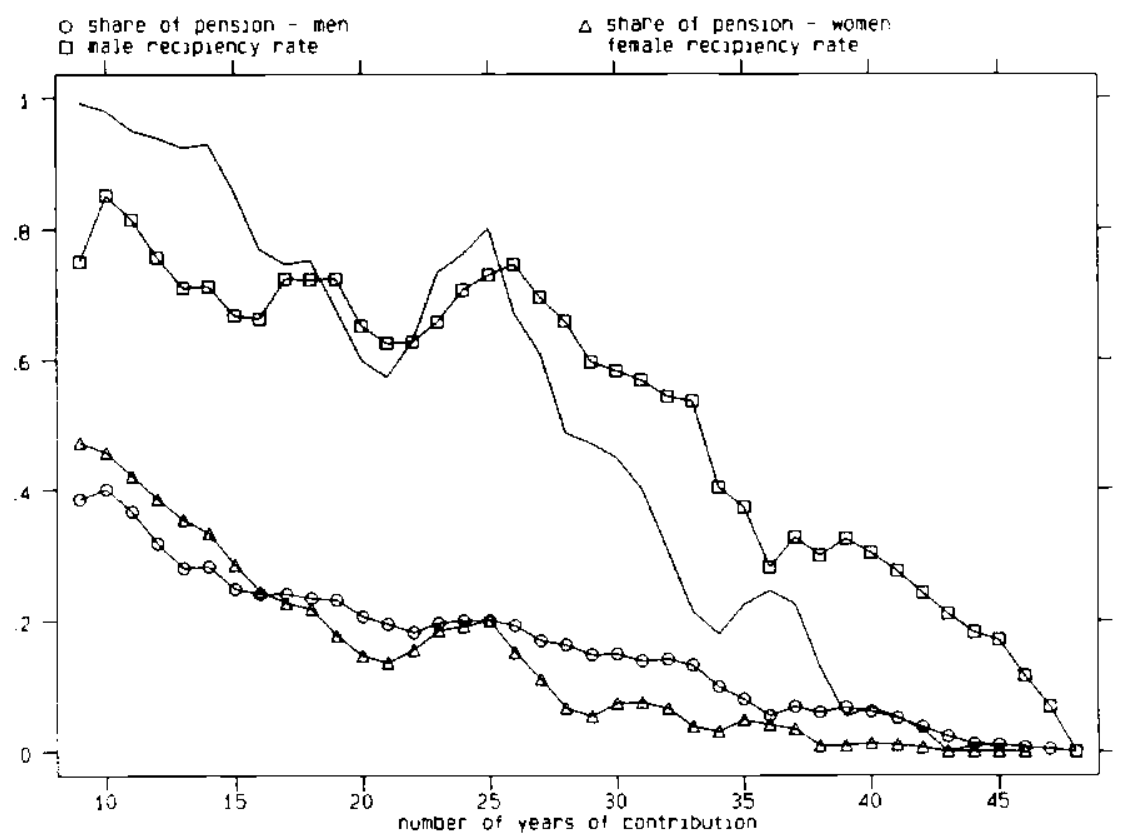


Figure 14: Distribution of male disability pensions outstanding in 1993 by age group and year of award.

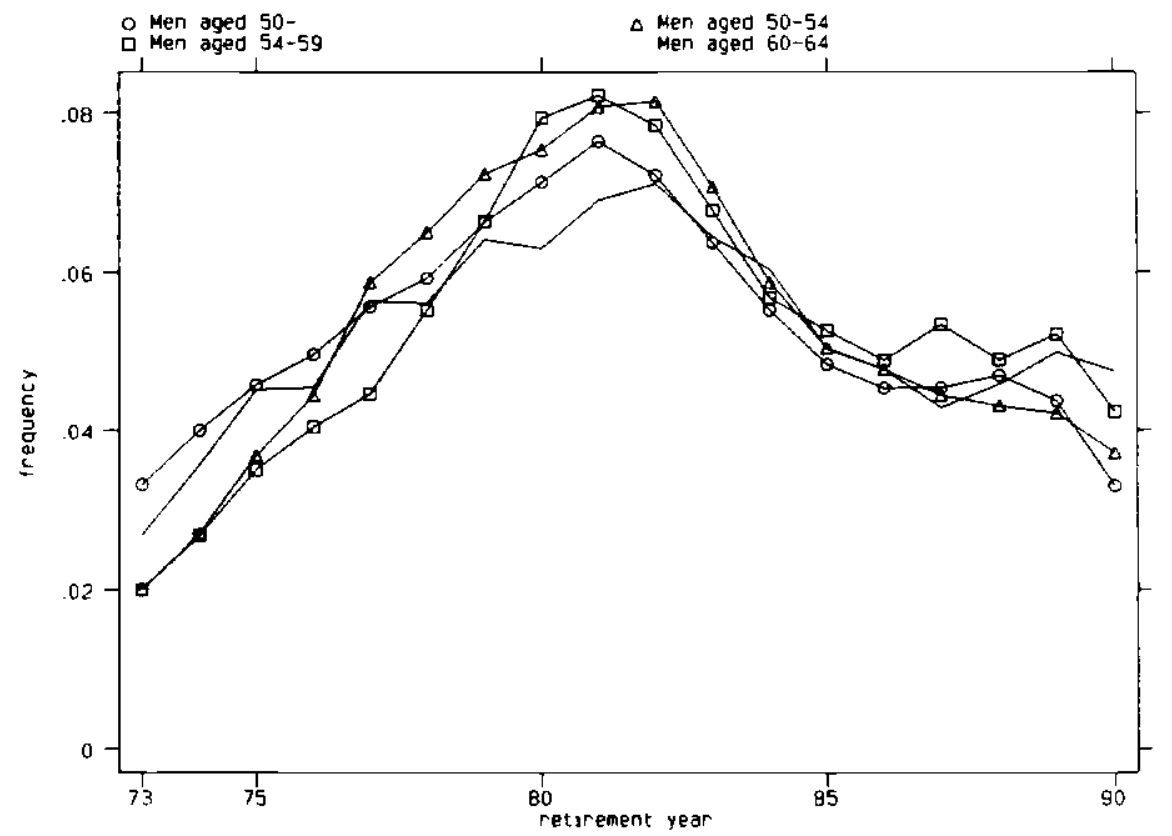


Figure 15: Tax/subsidy rates across earnings profiles.

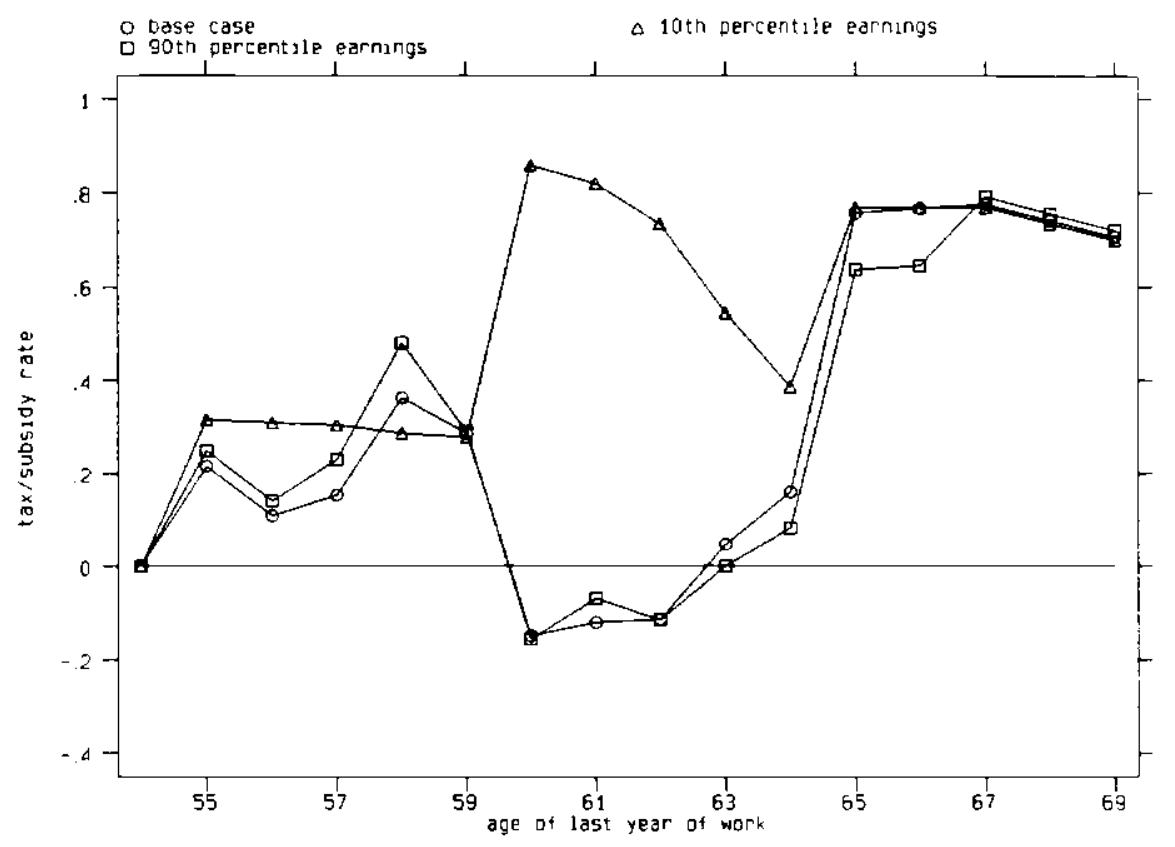


Figure 16: Hazard rate out of the labor force for men.

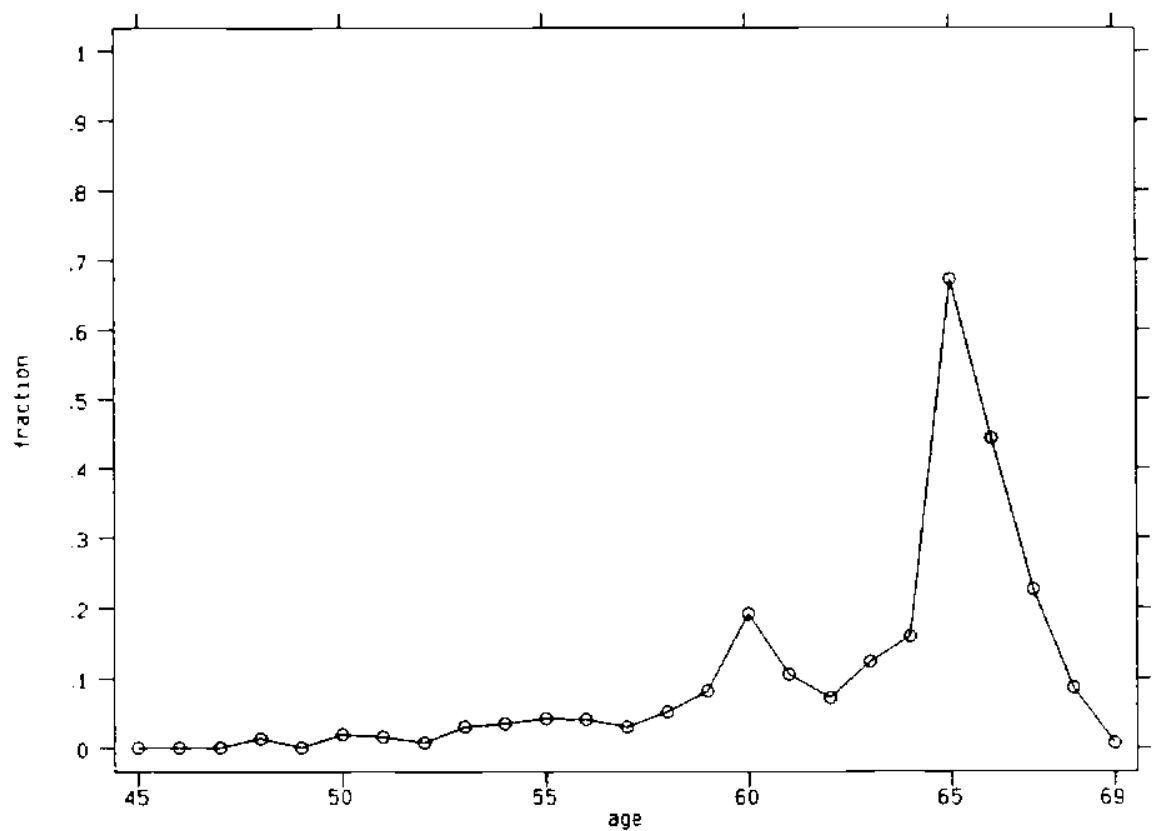


Figure 17: Hazard rate out of the labor force for women.

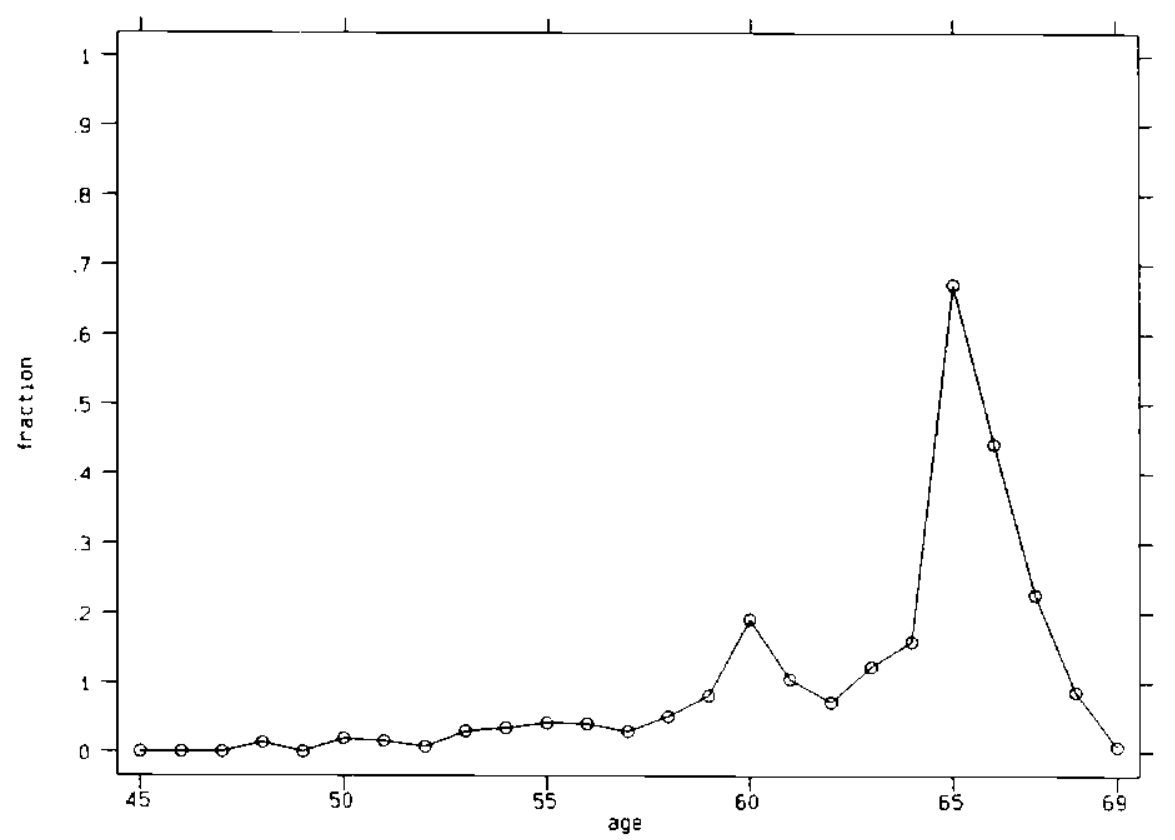

